\title{
Cross-Sectional and Time-Series Momentum Returns: Are Islamic Stocks Different?
}

\author{
Muhammad A. Cheema, Gilbert V. Nartea
}

\begin{abstract}
We search for differences in both unconditional and conditional momentum returns of Islamic and Non-Islamic stocks and test implications of competing behavioral theories that aim to explain momentum returns. Our results show that there is no significant difference in momentum returns between Islamic versus Non-Islamic stocks with respect to both crosssectional (CS) and time-series (TS) momentum strategies even when we condition momentum returns on market dynamics, information uncertainty $(I U)$, and idiosyncratic volatility $(I V)$. We also find that the TS strategy outperforms (underperforms) the CS strategy in market continuations (transitions) consistent with the recent evidence in the U.S. market. Furthermore, we find that CS and TS strategies of both Islamic and Non-Islamic stocks are profitable only when the market continues in the same state consistent with overconfidence driving momentum returns of both Islamic and Non-Islamic stocks.
\end{abstract}




\section{Cross-Sectional and Time-Series Momentum Returns and Market Dynamics: Are Islamic Stocks Different?}

\section{Introduction}

The momentum trading strategy is one of the most enduring stock market anomalies (e.g. Fama 1998). Two prominent strategies that can be employed to implement momentum trading are the cross-sectional (CS) and time-series (TS) strategies. The CS strategy of Jegadeesh and Titman (1993) buys (sells) stocks with higher (lower) returns than the crosssectional average over the past three to 12 months, whereas the TS strategy of Moskowitz, Ooi, and Pedersen (2012) buys (sells) stocks with excess positive (negative) returns over the risk-free rate during the ranking period.

Recent studies appear to rely increasingly on behavioral models to explain the profitability of the momentum strategy (Asem and Tian 2010; e.g. Arena, Haggard, and Yan 2008; Jiang, Lee, and Zhang 2005; Zhang 2006), with the two main competing behavioral models being the overconfidence model of Daniel, Hirshleifer, and Subrahmanyam (1998) and underreaction models of Hong and Stein (1999) and Barberis, Shleifer, and Vishny (1998).

Daniel, Hirshleifer, and Subrahmanyam (1998, DHS henceforth) propose a model in which investors simultaneously underreact to public information and overreact to their private information due to overconfidence and biased self-attribution. They argue that overconfidence changes over time as people receive feedback on their decisions, such that overconfidence increases (decreases) with confirming (disconfirming) feedback. In addition, they suggest that in general, overconfidence increases because of self-attribution bias as investors attribute success to their skills and failure to bad luck. Hence, on average new information increases investor overconfidence. Consequently, Asem and Tian (2010) argue that the DHS model predicts higher momentum returns when the market continues in the 
same state either UP or DOWN, than when it transitions to a different state because investor overconfidence increases if price appreciates (depreciates) following a buy (sell) trade. They condition momentum returns on the past and subsequent market states and indeed find higher momentum returns in the U.S. only when markets continue in the same state, i.e., UP or DOWN. ${ }^{1}$ Jiang, Lee, and Zhang (2005) and Zhang (2006) find higher momentum returns for firms with high information uncertainty $(I U)$ and suggest that their results are also consistent with the behavioral model of DHS since investor overconfidence is higher when confronted with firms that are difficult to value. Furthermore, Arena, Haggard, and Yan (2008) find higher momentum returns in the U.S. for firms with high idiosyncratic volatility $(I V)$, arguing that their findings are also consistent with the DHS model to the extent that high $I V$ stocks are difficult to value.

Barberis, Shleifer, and Vishny (1998, BSV henceforth) present a model based on the conservatism and representativeness biases. In their model, conservatism bias causes investors to underreact to new public information, which slows the information's impact on stock prices, while representativeness bias leads to delayed overreaction. Hong and Stein (1999, HS henceforth) present a model based on two groups of investors; news watchers (momentum traders) that rely on private information (past trend) for their trades. Based on the assumption of slow diffusion of private information into prices, their model predicts initial underreaction to the news that results in a positive serial correlation in returns which then attracts the attention of momentum traders. Consequently, in an environment of lower risk aversion, the trading activity of momentum traders could lead to greater overreaction which increases momentum returns. Therefore, Asem and Tian (2010) argue that the HS

\footnotetext{
${ }^{1}$ They define past market state as "UP" ("DOWN") when the past 12-month market return is nonnegative (negative). In addition, they classify the subsequent market state as "UP" ("DOWN") when the subsequent month market return is nonnegative (negative).
} 
model predicts higher momentum returns when the market continues UP or transitions UP, because increased wealth during UP markets reduces investor risk aversion.

Based on the BSV and HS models, Arena, Haggard, and Yan (2008) predict higher momentum returns for high $I V$ firms. This follows to the extent that $I V$ is a proxy for firmspecific information, with high $I V$ firms expected to suffer from higher underreaction compared to low $I V$ firms. Arena et al. (2008) condition momentum returns on $I V$ and find higher (lower) momentum returns for high (low) $I V$ firms, consistent with the implications of the BSV and HS models. However, McLean (2010) disputes their results arguing that they are biased due to the exclusion of small size and low price stocks which have relatively higher $I V$. McLean (2010) finds that the inclusion of these stocks, in fact, results in weaker momentum returns for high $I V$ firms compared to the other firms.

In sum, the behavioral models of DHS, BSV, and HS have specific time-series and cross-sectional implications on the profitability of momentum strategy. For example, the DHS model has both time-series and cross-sectional implications since it predicts higher momentum returns when the market continues in the same state (time-series implication) and higher momentum returns for difficult compared with easy to value firms (cross-sectional implication). The HS model also has both time-series and cross-sectional implications since it predicts higher momentum returns when the subsequent market is UP (time-series implication) and higher momentum returns for high $I U$ and $I V$ firms relative to low $I U$ and $I V$ firms (cross-sectional implication) because firms with higher $I U$ and higher $I V$ are expected to suffer from higher underreaction. The BSV model has only a cross-sectional implication predicting higher momentum returns for high $I U$ and $I V$ firms. We summarize the predictions of these models in Table 1. 
CS and TS momentum returns have been documented in multiple asset classes, i.e., stocks, futures, currencies, and commodities (e.g. Asness, Moskowitz, and Pedersen 2013; Moskowitz, Ooi, and Pedersen 2012; Goyal and Jegadeesh 2015). However, only a few studies examine the profitability of momentum returns in Sharia compliant (Islamic) stocks (e.g. Narayan and Phan 2017; Narayan et al. 2017; Li, Ee, and Rashid 2016). ${ }^{2}$ Narayan and Phan (2017) use a sample of 532 Islamic stocks listed in the U.S. Dow Jones Islamic index, and report significant momentum returns for Islamic stocks that are dependent on stock characteristics, e.g., they find higher momentum returns for small size stocks. Furthermore, Narayan and Phan (2017) show that momentum returns of Islamic stocks are merely a compensation for risk factors. They also show that momentum returns of Islamic stocks are 0.14 percent per month higher than momentum returns of conventional stocks; however, they do not indicate whether the difference in momentum returns between Islamic and conventional stocks is statistically significant or not. In a related study, Narayan et al. (2017) using a sample of 188 Islamic stocks listed in the Dow Jones Islamic Market Asia-Pacific Index (DJIMAP) show that momentum profits exist irrespective of the credit quality of stocks; however, a portfolio of stocks with low credit quality earns 4.68 percent per annum higher momentum returns relative to a portfolio of stocks with high credit quality. In sum, both studies provide evidence of momentum returns in stocks listed in Dow Jones Islamic Index and show that the momentum profitability of Islamic stocks is related to the risk factors. However, these studies do not test the implications of behavioral models to explain momentum returns of Islamic stocks in spite of the fact that the growing evidence in the

\footnotetext{
${ }^{2} \mathrm{Li}$, Ee, and Rashid (2016) examine the presence of CS momentum returns in Islamic stocks of Malaysia and find significant momentum returns in Islamic but weak momentum returns in non-Sharia compliant (NonIslamic) stocks. However, their methodology and data raise a few questions. For example, they use decile portfolios inspite of dealing with a small number of Non-Islamic stocks in their sample. Furthermore, they report negative average monthly returns for both loser and winner portfolios of Islamic and Non-Islamic stocks over the sample period of 2000-2014 despite of the fact that FTSE Bursa Malaysia KLCI increased almost two times over their sample period, from 922.10 to 1781.26 .
} 
literature shows that momentum profitability is related to the behavioral biases instead of risk factors (e.g. Fama and French 2008; Chui, Titman, and Wei 2010; Cooper, Gutierrez, and Hameed 2004; Asem and Tian 2010; Cheema and Nartea 2017). Another limitation of these studies is that they examine only CS but not TS momentum returns. It is important to examine the profitability of the TS strategy since it is relatively more profitable than the CS strategy (e.g. Moskowitz, Ooi, and Pedersen 2012).

Sharia-compliant stocks are those where the contribution of Sharia-compliant activities to the revenue of the company is not less than 95 percent (Shariah advisory council of the securities commission Malaysia, 2015). Therefore, the companies whose major business involves alcohol, pork-related products, tobacco, conventional banking for instance, are not considered as Sharia-complaint companies. Presumably, Muslim investors are more inclined to invest in Islamic stocks than Non-Islamic stocks because the former are in accord with the principles of Islamic law. The Malaysian stock market is unique because it trades both Sharia and non-Sharia-compliant stocks with the former classified by the Sharia Advisory Council of the Securities Commission Malaysia. ${ }^{3}$

In this paper, we empirically examine the profitability of both the CS and TS momentum returns in an emerging market that trades both Islamic and Non-Islamic stocks. More importantly, we examine if Islamic stocks behave differently from Non-Islamic stocks. Furthermore, we test whether behavioral theories can explain momentum returns in an emerging market that trades both Islamic and Non-Islamic stocks. Specifically, we condition both CS and TS momentum returns on market dynamics, information uncertainty proxies and idiosyncratic volatility as a proxy for firm-specific information.

\footnotetext{
${ }^{3}$ We chose Malaysia mainly because the Sharia Advisory Council of the Securities Commission Malaysia classifies firms into Sharia and non-Sharia complaint stocks whereas in other countries/Islamic indexes private sharia boards classify firms into Sharia and non-Sharia compliant stocks. Adam and Bakar (2014) show that the Sharia Advisory Council of the Securities Commission Malaysia uses additional screening criteria to classify securities as sharia-compliant compared with the screening criteria used by Dow Jones Islamic Market Indexes.
} 
Using a sample of 504 Islamic and 381 Non-Islamic stocks, we find that there is no significant difference in Islamic versus Non-Islamic stocks either in the level or pattern of momentum returns. Therefore, investors in Islamic stocks can execute momentum strategies without loss of efficacy compared with Non-Islamic stocks. Specifically, first we find large and significant CS and TS momentum returns for both Islamic and Non-Islamic stocks when the market continues in the same state than when it transitions to a different state consistent with the conditional momentum returns pattern in other markets i.e., U.S., Japan, etc. (Cheema, Nartea, and Szulczyk 2018; Asem and Tian 2010) and supports the overconfidence model of DHS. Second, we find that for both Islamic and Non-Islamic stocks, the TS strategy outperforms (underperforms) the CS strategy in market continuations (transitions) because the TS strategy takes a net long (short) position following UP (DN) markets, consistent with the findings of Cheema, Nartea, and Man (2017) for the U.S. market. Third we find that the positive relation between $I U$ and momentum returns as well as the positive relation between $I V$ and momentum returns found in the U.S. stock markets is absent in both Islamic and NonIslamic stocks in the Malaysian stock market. This is contrary to the prediction of both the overconfidence model of DHS, and the underreaction models of BSV and HS. However as we also find that momentum returns in Malaysia are conditioned by market states, it appears that momentum behavior in the Malaysian stock market is more consistent with the overconfidence rather than the underreaction model.

Our study makes two important contributions to the momentum literature. First, as far as we are aware, we are the first to show that there is no difference in the profitability of both the CS and TS momentum returns between Islamic versus Non-Islamic stocks. Second, we provide evidence that the DHS model explains the CS and TS momentum returns of both Islamic and Non-Islamic stocks. 
The rest of the paper is organised as follows. Section 2 describes our data and methodology. Section 3 presents the empirical results, Section 4 discusses the potential explanations and Section 5 concludes.

\section{Data and Methods}

\subsection{Data}

We collect data for Malaysian stocks from DataStream International from January 1990 to December 2014. We include all common stocks with primary quotes denominated in Malaysian Ringgit that are listed on Malaysian stock exchanges. We use the list of Shariacompliant stocks provided by the Sharia Advisory Council of the Securities Commission Malaysia to identify Sharia-compliant stocks (Shariah advisory council of the securities commission Malaysia, 2015). ${ }^{4}$

Following Chui, Titman, and Wei (2010), we set returns greater (less) than 100 percent (-95 percent) equal to 100 percent (-95 percent) to avoid the influence of extreme returns and data recording errors. Since DataStream does not provide monthly returns, we use the return index (RI) to calculate monthly returns. DataStream sets the value of the return index equal to the last index value if the stock is not traded. Therefore, the returns data calculated from this index contain many zero values. To ensure that the zero returns are not the result of zero trading volume, we follow Chui, Titman, and Wei (2010) and calculate the return for a stock in month $t$ if its trading volume was available for months $t$ and $t-1$. For missing trading volume data, we only include those monthly returns in our sample if it is not equal to zero. Following Chui, Titman, and Wei (2010), we require each stock in our sample to have a history of at least eight months at the portfolio formation date.

\footnotetext{
${ }^{4}$ Shariah advisory council of the securities commission Malaysia updates its list of Sharia-compliant stocks on a yearly basis. As a robustness test, we add/exclude stocks based on those updates and our results remain similar. These results are available from the authors upon request.
} 
We use firm size $(M V)$, firm age $(A G E)$, idiosyncratic volatility $(I V)$, turnover (TOVER), and volatility ( $V O L)$ as information uncertainty proxies. $M V$ is the market capitalization (in millions) of each firm at the portfolio formation date. $A G E$ is defined as the difference in months between the listed date on DataStream and current month $t$. VOL is the standard deviation of monthly returns for the past 12 months at the portfolio formation date. TOVER is defined as the average daily turnover in the past six months, where daily turnover is equal to the number of shares traded divided by the number of shares outstanding for each day. $I V$ is the standard deviation of the residuals from the following market model equation:

$$
r_{i, t}=\alpha_{i}+\beta_{i 1} r m_{t}+e_{i, t}
$$

where $r_{i, t}$ is the monthly return on stock $i ; r m_{t}$ is the FTSE Bursa Malaysia KLCI index return, and $e_{i, t}$ is the regression residual. We estimate equation (1) for each stock on the formation date using monthly data over the past 12 -month period $(t-12$ to $t-1) .^{5}$

Our sample includes 504 Islamic and 381 Non-Islamic stocks that meet our criteria to be included in a momentum portfolio.

\subsection{Methods}

First, we calculate equally-weighted CS and TS momentum returns for Islamic and Non-Islamic stocks as in Goyal and Jegadeesh (2015). ${ }^{6}$ At the beginning of each month $t+1$, we sort stocks based on their past 6-month returns ( $t-6$ to $t-1)$ and hold these portfolios for the next 6-months ( $t+1$ to $t+6)$, skipping month $t$ to mitigate the bid-ask bounce effect. ${ }^{7}$ We use overlapping portfolios as in Jegadeesh and Titman (1993).

\footnotetext{
${ }^{5}$ We require a stock to have at least 10 valid monthly return observations in a 12 -month period to estimate IV. We chose a 12-month period to calculate the idiosyncratic volatility (IV) to make sure we have enough number of stocks to form momentum portfolios in our sample especially at the beginning of the sample period. Our results remain similar if we calculate the IV based on a longer time-frame (e.g., 36-month returns) as in McLean (2010).

${ }^{6}$ The CS momentum returns remain robust for value-weighted portfolios. The TS methodology is not suitable for value-weighted portfolios. However, we exclude stocks below the 20th percentile of market capitalization and our results remain similar. These results are available from the authors upon request.

${ }^{7}$ We use the conventional 6-month formation and holding periods for our momentum strategy; However, our results remain similar for 3-, 9- and 12-month formation and holding periods as well.
} 
For the CS strategy, we buy (sell) the stocks with returns greater (lower) than the cross-sectional average. The momentum returns for the CS strategy refer to the difference of the excess returns between buy and sell portfolios as shown below. ${ }^{8}$

$$
C S-M O M_{t}=\frac{1}{N^{+}} \sum_{R_{i t-1} \geq R_{t-1}} R_{i t}-\frac{1}{N^{-}} \sum_{R_{i t-1}<R_{t-1}} R_{i t}
$$

$C S-M O M_{t}$ is the momentum return for the CS strategy for month $t . R_{i t-l}$ is the formation period return of stock $i$, while $R_{t-1}$ is the cross-sectional average of the formation period returns. $N^{+}\left(N^{-}\right)$is the number of stocks with returns greater (lower) than the crosssectional average formation period returns. The CS strategy invests $\$ 1$ both in buy and sell portfolios by construction.

For the TS strategy, we take a long (short) position in stocks with excess returns higher (lower) than zero. The momentum returns for the TS strategy refer to the difference in the excess returns between buy and sell portfolios as shown below. ${ }^{9}$

$$
T S-M O M_{t}=\frac{2}{N}\left(\sum_{R_{i t-1} \geq 0} R_{i t}-\sum_{R_{i t-1<0}} R_{i t}\right)
$$

$T S-M O M_{t}$ is the momentum return for the TS strategy for month $t$. We use a numerator of two in equation 2 to ensure that the TS strategy is comparable to the CS strategy.

We also provide risk-adjusted momentum returns for both CS and TS strategies. To calculate risk-adjusted momentum returns, we obtain factor loadings $(\beta)$ by regressing the time series of momentum returns on the CAPM (RMRF) and Fama-French risk factors (RMRF, SMB and HML) and a constant. RMRF is the excess return of the FTSE Bursa Malaysia KLCI index return over the one-month Treasury bill rate. SMB is the small-minus-

\footnotetext{
${ }^{8}$ The excess momentum returns for the CS strategies are equal to the raw momentum returns because both winner and loser portfolios take equal positions in stocks.

${ }^{9}$ We make the assumption of borrowing (investing) at risk-free rate if the long position is larger (smaller) than the short position.
} 
big size premium, and HML is the high-book-to-market-minus-low-book-to-market premium. ${ }^{10}$ The risk adjusted momentum returns of each month are

$$
M R_{t}^{a d j}=M R_{t}-\sum \beta_{i} f_{i t}
$$

where $M R_{t}$ is the raw momentum returns for month $t, f_{i t}$ is the realization of factor $i$ in month $t$, and $\beta_{i}$ is the factor loadings.

\section{Empirical Results}

\subsection{Descriptive Statistics}

Table 2 shows the descriptive statistics of our main variables. The mean return of Islamic stocks (1.47 percent per month) is slightly higher than the mean return of NonIslamic stocks (1.38 percent per month), but their standard deviations are practically the same. The mean price of Islamic stocks at 2.47 Malaysian Ringgit (RM) is slightly lower than the mean price of Non-Islamic stocks at 2.68 RM. The mean $M V$ of Islamic stocks at 974 million RM is slightly lower than the mean $M V$ of Non-Islamic stocks at 1138 million RM. Interestingly, the returns, price and market capitalization of Islamic and Non-Islamic stocks are highly correlated with each other which indicates that there is no difference in the characteristics of both Islamic and Non-Islamic stocks.

(Table 2 about here.)

\subsection{Unconditional Momentum Returns}

Table 3 presents CS and TS momentum returns of Islamic and Non-Islamic stocks for momentum portfolios of 6-month formation and 6-month holding periods. We find insignificant momentum returns for both Islamic and Non-Islamic stocks irrespective of whether we use CS or TS strategy. CS momentum returns of Islamic stocks are 0.15 percent

\footnotetext{
${ }^{10}$ We generate SMB and HML values following procedures described Fama and French (1993).
} 
per month compared with 0.16 percent per month for Non-Islamic stocks. ${ }^{11}$ TS momentum returns of Islamic stocks are 0.73 percent per month compared with 0.84 percent per month for Non-Islamic stocks. ${ }^{12}$ The CAPM- and Fama-French-(FF)adjusted momentum returns exhibit the same pattern as those of the unadjusted momentum returns. Most importantly, the last column (A-B) of Table 3 shows that the difference in momentum returns between Islamic and Non-Islamic stocks is small and statistically not different than zero whether we use CS or TS strategy. It is also interesting to note that TS momentum returns are almost five times larger than CS momentum returns for both Islamic and Non-Islamic stocks.

(Table 3 about here.)

\subsection{Momentum Returns and Market Dynamics}

Next we examine the relation between momentum returns and market dynamics.

Table 4 presents CS and TS momentum returns of Islamic and Non-Islamic stocks sorted on lagged and subsequent market states. We define the lagged market state based on the return of the FTSE Bursa Malaysia KLCI Index returns over months $t-11$ to $t$ and the subsequent market state based on the FTSE Bursa Malaysia KLCI Index returns for month $t+1$. If the lagged and subsequent market returns are both non-negative (negative), the market dynamics is described as UP/UP (DN/DN). If the lagged market return is non-negative (negative), and

\footnotetext{
${ }^{11} \mathrm{We}$ also find insignificant unconditional CS momentum returns for other holding periods. For example, CS momentum returns for Islamic stocks are 0.21 percent per month $(t$-stat $=0.94), 0.05$ percent per month $(t$-stat $=$ $0.28),-0.04$ percent per month $(t$-stat $=-0.26)$ for 3-, 9- and 12-month holding periods, respectively. CS momentum returns for Non-Islamic stocks are 0.23 percent per month $(t$-stat $=0.95), 0.02$ percent per month $(t$ stat $=0.12),-0.02$ percent per month $(t$-stat $=-0.12)$ for 3-, 9- and 12-month holding periods, respectively. Furthermore, we do not find any significant difference in momentum returns between Islamic versus NonIslamic stocks. We do not tabulate these results to save space.

${ }^{12} \mathrm{We}$ also find insignificant unconditional TS momentum returns for other holding periods. For example, TS momentum returns for Islamic stocks are 0.99 percent per month $(t$-stat $=1.10),-0.05$ percent per month $(t$-stat $=-0.07),-0.46$ percent per month $(t$-stat $=-0.69)$ for 3-, 9- and 12-month holding periods, respectively. TS momentum returns for Non-Islamic stocks are 1.04 percent per month $(t$-stat $=1.15), 0.09$ percent per month $(t$ stat $=0.12),-0.29$ percent per month $(t$-stat $=-0.42)$ for 3-, 9- and 12-month holding periods, respectively. Furthermore, we do not find any significant difference in momentum returns between Islamic versus NonIslamic stocks. We do not tabulate these results to save space.
} 
subsequent market return is negative (non-negative), the market dynamics is described as UP/DN (DN/UP).

Table 4 shows that irrespective of whether stocks are Islamic or Non-Islamic, momentum returns are larger when the market continues in the same state than when it transitions to a different state. This momentum return behavior is consistent with the patterns in other markets, i.e., U.S., Japan, etc. (e.g. Asem and Tian 2010; Cheema, Nartea, and Szulczyk 2018), and supports the overconfidence model of DHS. Panel A of Table 4 shows that CS momentum returns for Islamic stocks are 0.62 (1.34) percent per month when the market continues in the UP (DN) state while it is only $0.24(-2.18)$ percent per month when the market transitions from the UP (DN) to the DN (UP) state. Similarly, for Non-Islamic stocks, CS momentum returns are 0.45 (1.97) percent per month when the market continues in the UP (DN) state, while momentum returns are $0.42(-2.48)$ percent per month when the market transitions from UP (DN) to DN (UP) state. ${ }^{13}$ The CAPM- and FF-adjusted momentum returns are significant when the market continues in the same state and when it transitions to the UP state (DN/UP).

We obtain the same patterns for TS momentum returns as reported in Panel B of Table 4. TS momentum returns for Islamic stocks are 3.33 (8.95) percent per month when the market continues in the UP (DN) state, while momentum returns are -1.94 (-8.10) percent per month when the market transitions from UP (DN) to DN (UP) state. Similarly, for NonIslamic stocks, TS momentum returns are 3.44 (9.97) percent per month when the market continues in the UP (DN) state, while momentum returns are $-1.72(-8.96)$ percent per month when the market transitions from UP (DN) to DN (UP) state. The CAPM- and FF-adjusted

\footnotetext{
${ }^{13}$ The raw momentum returns of Non-Islamic stocks are statistically significant when the market transitions from UP to DN state; however, the CAPM- and FF-adjusted momentum returns are negative but insignificant.
} 
momentum returns bear the same sign as raw momentum returns and almost all of them are significant.

Most importantly, the last column (A-B) of Table 4 shows that the difference in momentum returns between Islamic and Non-Islamic stocks is small and insignificant irrespective of the momentum strategy and market dynamics. However, we find that TS momentum returns for both Islamic and Non-Islamic stocks are higher (lower) than CS momentum returns in market continuations (transitions) since the TS strategy takes a net long (short) position following UP (DN) markets. For example, we find that the TS strategy takes a net long position for 156 out of 203 months following UP, and net short position for 67 out of 85 months following DOWN markets, which results in comparatively higher (lower) returns for the TS strategy because of positive (negative) autocorrelation between the active position and subsequent market returns in market continuations (transitions). Our results are consistent with Cheema, Nartea, and Man (2017) for the U.S. market.

(Table 4 about here.)

\subsection{Momentum Returns and Information Uncertainty}

In this section we examine the relation between momentum returns and information uncertainty $(I U)$ proxies. Based on the overconfidence model of DHS, Jiang, Lee, and Zhang (2005) and Zhang (2006) argue that momentum returns would be higher in high IU firms because investors tend to be more overconfident when dealing with firms that are difficult to value. Jiang et al. (2005) independently sort stocks into momentum portfolios based on past returns and into $I U$ portfolios based on the cross-sectional variation in the level of $I U$. They find higher momentum returns for high $I U$ firms in the U.S., consistent with the DHS model. Thus, using $I U$ as an additional proxy for overconfidence we test if high $I U$ firms have higher momentum returns. More importantly we examine if momentum returns of Islamic and NonIslamic will differ once conditioned on $I U$. 
Tables 5 and 6 present CS and TS momentum returns of Islamic and Non-Islamic stocks sorted on each $I U$ proxy, respectively. ${ }^{14}$ At the beginning of each month $t+1$, we independently sort stocks into halves based on each $I U$ proxy and into halves based on past 6month returns using equations 2 (CS) and 3 (TS). We hold these portfolios for 6-months $(t+1$ to $t+6)$. Following Jegadeesh and Titman (1993), we use overlapping portfolios.

(Table 5 about here.)

Our general results in Tables 5 and 6 show that $I U$ is unrelated to both CS and TS momentum returns for both Islamic and Non-Islamic stocks. Panel A of Table 5 reports CS momentum returns sorted on firm size. The difference in momentum returns (MOMHMOML) between high and low $I U$ Islamic (Non-Islamic) stocks is $-0.31(0.07)$ percent per month but statistically insignificant. Panels B to E of Table 5 also show that there is no significant relation between momentum returns and our other $I U$ proxies for both Islamic and Non-Islamic stocks, similar to the results shown in Panel A. Our Table 6 results also show that there is no relation between TS momentum returns and $I U$. Most importantly, the last column (A-B) of Tables 5 and 6 shows that there is no significant difference in momentum returns between Islamic and Non-Islamic stocks for all the $I U$ proxies.

(Table 6 about here.)

In sum, we find no relation between momentum returns and information uncertainty contrary to Jiang, Lee, and Zhang (2005) and Zhang (2006) for the U.S. markets. In particular, we also do not find a relation between $I V$ and momentum returns contrary to the U.S. results of Arena, Haggard, and Yan (2008), but consistent with McLean (2010). More importantly, we find that our results apply equally to both Islamic and Non-Islamic stocks.

\footnotetext{
${ }^{14}$ In results not reported here we also perform dependent sorts and find similar results. These results are available from the authors upon request.
} 
Therefore, unlike in the U.S. stock markets, these results are not supportive of either the overconfidence model of DHS or the underreaction models of BSV and HS.

\subsection{Momentum Returns, Information Uncertainty and Market Dynamics}

Since we find in Section 3.3 that momentum returns are stronger when markets continue in the same direction, we further examine the relation between momentum returns and information uncertainty conditioned on market dynamics.

Tables 7 and 8 present CS and TS momentum returns of Islamic and Non-Islamic stocks conditioned on $I U$ and market dynamics. At the beginning of each month $t+1$, we independently sort stocks into halves based on each $I U$ proxy and into halves based on past 6month returns using equations 2 (CS) and 3 (TS). Furthermore, we define market states based on lagged market returns over month $t-11$ to $t$ and subsequent market returns for month $t+1$ as in Section 3.3. We hold these portfolios for 6-months $(t+1$ to $t+6)$. Following Jegadeesh and Titman (1993), we use overlapping portfolios.

(Table 7 about here.)

Table 7 reports CS momentum returns conditioned on $I U$ and market dynamics. Recall from Panel A of Table 4 that we find significant momentum returns when the market continues in the same state. Table 7 shows that we generally find higher momentum returns when the market continues in the same state even when we condition on $I U$, which is consistent with results shown in Table 4. Panel A of Table 7 reports CS momentum returns sorted on firm size and conditioned on market dynamics. We find that momentum returns of the low (high) IU portfolio of Islamic stocks are $0.85(0.42)$ percent per month when the market continues in UP state and 1.88 (1.13) percent per month when the market continues in 
DN state. ${ }^{15}$ The momentum returns of the low (high) $I U$ portfolio of Islamic stocks are 0.40 (0.21) percent per month when the market transitions from UP to DN state and -1.82 (-1.74) percent per month when the market transitions from DN to UP state. The momentum returns of the low (high) $I U$ portfolio of Non-Islamic stocks are $0.34(0.53)$ percent per month when the market continues in UP state and 2.44 (1.82) percent per month when the market continues in DN state. The momentum returns of the low (high) $I U$ portfolio of Non-Islamic stocks are $0.39(0.54)$ percent per month when the market transitions from UP to DN state and $-2.38(-2.24)$ percent per month when the market transitions from DN to UP state. Panels $\mathrm{B}$ to $\mathrm{E}$ of Table 7 show the same patterns for the rest of $I U$ proxies. Furthermore, momentum returns for $I U$ proxies especially for Non-Islamic stocks are positive and significant when the market transitions from UP to DN state; however, these momentum returns do not remain significant once adjusted for CAPM and FF risk factors. ${ }^{16}$

More importantly, we still do not find a significant positive relationship between momentum returns and $I U$ in Table 7 even when the market continues in the same state. The difference in momentum returns between high and low $I U$ portfolios (MOMH- MOML) are generally insignificant or negative, inconsistent with the view that higher $I U$ firms have higher momentum returns. For example, in Panel A we find that the difference in momentum returns between high and low $I U$ portfolios (MOMH-MOML) is $-0.43(0.19)$ percent per month for Islamic (Non-Islamic) stocks and is statistically insignificant when the market continues in the UP state. Likewise, the difference in momentum returns between high and low $I U$ portfolios (MOMH-MOML) is $-0.75(-0.60)$ percent per month for Islamic (NonIslamic) stocks when the market continues in the DN state and is statistically insignificant.

\footnotetext{
${ }^{15}$ Momentum returns of high $I U$ portfolio are insignificant. However, the un-reported CAPM and FF adjusted momentum returns of high $I U$ portfolio are significant.

${ }^{16}$ To save space, we do not report CAPM and FF adjusted momentum returns. These results are available from the authors upon request.
} 
These results are inconsistent with the view that higher $I U$ firms have higher momentum returns. Panels B to E show that the same pattern holds for the rest of the $I U$ proxies.

Table 8 presents TS momentum returns conditioned on $I U$ and market dynamics. Similar to the CS momentum returns shown in Table 7, our results in Table 8 also show that in general there is no robust positive relation between TS momentum returns and $I U$ even when conditioned on market dynamics. The difference in momentum returns between high and low $I U$ portfolios (MOMH- MOML) are generally insignificant or negative. ${ }^{17}$

(Table 8 about here.)

In sum, we generally do not find a positive relation between $I U$ and momentum returns for both Islamic and Non-Islamic stocks even when we condition momentum returns on market dynamics. Furthermore, the last column (A-B) of Tables 7 and 8 shows that there is no significant difference in momentum returns between Islamic and Non-Islamic stocks even when we condition stocks on $I U$ and market dynamics.

\section{Potential Explanations}

Our results show that both CS and TS momentum returns are higher when the market continues in the same state which is consistent with the overconfidence model of DHS and in line with prior evidence in other markets, i.e. U.S., Japan, etc. (e.g. Asem and Tian 2010; Cheema, Nartea, and Szulczyk 2018). However, we do not find support for the DHS model when we use $I U$ as a proxy of overconfidence, inconsistent with the evidence in the U.S. market (e.g. Jiang, Lee, and Zhang 2005).

We suggest that our result based on $I U$ differs from the prior evidence from the U.S. market because of differences in investor behavior in the Malaysian and U.S. markets. The

\footnotetext{
${ }^{17}$ We find a significant positive relation at 5 percent level between momentum returns and $I U$ for six out of 40 observations in Table 8 . This could just be a random effect as 34 out of 40 observations show that there is a negative or insignificant positive relation between momentum returns and $I U$.
} 
U.S. market is said to be efficient (e.g. Fama 1970; Bai, Philippon, and Savov 2016) where investors rely on firm-specific public information to make investment decisions.

Consequently, based on the DHS model, investor overconfidence would be higher when valuing high $I U$ firms as they are difficult to value. These overconfident investors overweight (underweight) their private (public) information which results in relatively higher momentum returns for high $I U$ firms compared with other firms as shown in Jiang, Lee, and Zhang (2005) and Zhang (2006). However, the Malaysian market is considered to be relatively inefficient (e.g. Kim and Shamsuddin 2008; Hoque, Kim, and Pyun 2007) where investors rely more on rumors and private information (e.g. Mansor and Lim 1995) than on firmspecific public information; therefore, $I U$ might not be a good proxy of investor overconfidence, hence it has a limited role in explaining momentum returns. As we also consider $I V$ as a proxy for both $I U$ and firm-specific information, our result suggesting no relation between $I V$ and momentum returns is also consistent with a market populated by investors who rely more on rumors than on firm-specific information.

In contrast, market dynamics can explain the time-series variation in momentum returns wherein momentum returns are higher when markets continue in the same state and are lower when markets transition to a different state presumably because investor overconfidence increases when the market continues in the same state and decreases when the market transitions to a different state. This is consistent with the overconfidence model of DHS. Therefore, based on our results we suggest that market dynamics is a good proxy for investor overconfidence in the Malaysian market.

In sum, our results suggest that there is no difference between Islamic and NonIslamic stocks when it comes to momentum returns even when we condition it on market dynamics, $I U$ and $I V$. Furthermore, the same behavioral bias, i.e., investor overconfidence, can explain momentum returns of both Islamic and Non-Islamic stocks which suggest that 
religious beliefs might not necessarily make any significant difference in the trading behavior of investors based on the presumption that the proportion of Muslim investors in Islamic stocks is higher than in Non-Islamic stocks. Thus, our results can be generalized to other Islamic markets to the extent that momentum is driven by the behavioral biases since we find that the same behavioral bias, i.e., investor overconfidence, explains momentum returns of both Islamic and Non-Islamic stocks.

\section{Conclusions}

In this paper, we search for differences in both unconditional and conditional momentum returns of Islamic and Non-Islamic stocks. We use both cross-sectional (CS) and time-series (TS) momentum returns and condition momentum returns on market dynamics, information uncertainty $(I U)$ and idiosyncratic volatility $(I V)$. Our results reveal no significant difference for both unconditional and conditional momentum returns of Islamic versus NonIslamic stocks whether we use the CS or TS strategy.

We further find that CS and TS momentum returns of both Islamic and Non-Islamic stocks are large and significant when the market continues in the same direction than when it transitions to a different state. Additionally, our results show that the TS strategy outperforms (underperforms) the CS strategy in market continuations (transitions) which is consistent with the recent evidence of Cheema, Nartea, and Man (2017) who find that the TS strategy outperforms (underperforms) the CS strategy in the U.S. because of the positive (negative) autocorrelations between net long/short position and subsequent market returns in market continuations (transitions). However, we do not find any relation between momentum returns and both $I U$ and $I V$.

Though our results on the relation between momentum returns and $I U$ or $I V$ are inconsistent with both the DHS model and the underreaction models of BSV and HS, our results on the relation between momentum returns and market dynamics are consistent with 
the overconfidence model of DHS to the extent that we find higher and significant momentum returns in market continuations. We suggest that the inconsistent results relative to $I U$ and momentum returns could be due to the presumption that investors in the Malaysian market rely less on firm-specific public information and more on rumors when making investment decisions. Therefore, $I U$ might not be a good proxy of investor overconfidence and thus have a limited role in explaining momentum returns. In the same way, to the extent that $I V$ is a proxy for firm-specific information, the absence of a relation between $I V$ and momentum returns is consistent with a market populated by investors who rely more on rumors than the firm-specific information. On balance therefore, we find that overconfidence bias is a more likely driver of momentum returns of Islamic and Non-Islamic stocks in the Malaysian stock market. 


\section{References}

Adam, Noor Latiffah, and Nordin Abu Bakar. 2014. "Shariah screening process in Malaysia." Procedia-Social and Behavioral Sciences 121:113-23.

Arena, M. P., K. S. Haggard, and X. S. Yan. 2008. "Price momentum and idiosyncratic volatility." The Financial Review 43 (2):159-90.

Asem, Ebenezer, and Gloria Y Tian. 2010. "Market dynamics and momentum profits." Journal of Financial and Quantitative Analysis 45 (6):1549-62.

Asness, Clifford S, Tobias J Moskowitz, and Lasse Heje Pedersen. 2013. "Value and momentum everywhere." The Journal of Finance 68 (3):929-85.

Bai, Jennie, Thomas Philippon, and Alexi Savov. 2016. "Have financial markets become more informative?" Journal of Financial Economics 122 (3):625-54.

Barberis, N., A. Shleifer, and R. Vishny. 1998. "A model of investor sentiment." Journal of Financial Economics 49 (3):307-43.

Cheema, Muhammad A, and Gilbert V Nartea. 2017. "Momentum, idiosyncratic volatility and market dynamics: Evidence from China." Pacific-Basin Finance Journal 46:10923.

Cheema, Muhammad A, Gilbert V Nartea, and Kenneth R Szulczyk. 2018. "Cross-sectional and time-series momentum returns and market dynamics: evidence from Japan." Applied Economics 50 (23):2600-12.

Cheema, Muhammad A., Gilbert V. Nartea, and Yimei Man. 2017. "Cross-Sectional and Time Series Momentum Returns and Market States." International Review of Finance:n/a-n/a. doi: 10.1111/irfi.12148.

Chui, Andy CW, Sheridan Titman, and KC John Wei. 2010. "Individualism and momentum around the world." The Journal of Finance 65 (1):361-92.

Commission, Securities. 2015. "List of Shariah-compliant securities by the Shariah advisory council of the securities commission Malaysia." Kuala Lumpur.

Cooper, Michael J, Roberto C Gutierrez, and Allaudeen Hameed. 2004. "Market states and momentum." The Journal of Finance 59 (3):1345-65.

Daniel, K. D., D. Hirshleifer, and A. Subrahmanyam. 1998. "Investor psychology and security market under- and overreactions." The Journal of Finance 53 (6):1839-85.

Fama, E. F. 1998. "Market efficiency, long-term returns, and behavioral finance." Journal of Financial Economics 49 (3):283-306. 
Fama, E. F., and K. R. French. 1993. "Common risk factors in the returns on stocks and bonds." Journal of Financial Economics 33 (1):3-56.

—. 2008. "Dissecting anomalies." The Journal of Finance 63 (4):1653-78.

Fama, Eugene F. 1970. "Efficient capital markets: A review of theory and empirical work." The Journal of Finance 25 (2):383-417.

Goyal, Amit, and Narasimhan Jegadeesh. 2015. "Cross-Sectional and Time-Series Tests of Return Predictability: What is the Difference?" Available at SSRN 2610288.

Hong, H., and J. C. Stein. 1999. "A unified theory of underreaction, momentum trading, and overreaction in asset markets." The Journal of Finance 54 (6):2143-84.

Hoque, Hafiz AAB, Jae H Kim, and Chong Soo Pyun. 2007. "A comparison of variance ratio tests of random walk: A case of Asian emerging stock markets." International Review of Economics \& Finance 16 (4):488-502.

Jegadeesh, Narasimhan, and Sheridan Titman. 1993. "Returns to buying winners and selling losers: Implications for stock market efficiency." The Journal of Finance 48 (1):6591.

Jiang, G., C. M. C. Lee, and Y. Zhang. 2005. "Information uncertainty and expected returns." Review of Accounting Studies 10 (2):185-221.

Kim, Jae H, and Abul Shamsuddin. 2008. "Are Asian stock markets efficient? Evidence from new multiple variance ratio tests." Journal of Empirical Finance 15 (3):518-32.

Li, Bob, Mong Shan Ee, and Mamunur Rashid. 2016. "Is momentum trading profitable from Shari'ah compliant stocks?" Review of Financial Economics.

Mansor, MI, and CF Lim. 1995. "Profile of individual investors in the Klang area." Capital Markets Review 3:1-15.

McLean, R. D. 2010. "Idiosyncratic risk, long-term reversal, and momentum." Journal of Financial and Quantitative Analysis 45 (04):883-906.

Moskowitz, Tobias J, Yao Hua Ooi, and Lasse Heje Pedersen. 2012. "Time series momentum." Journal of Financial Economics 104 (2):228-50.

Narayan, Paresh Kumar, Seema Narayan, Dinh Hoang Bach Phan, Kannan Sivananthan Thuraisamy, and Vuong Thao Tran. 2017. "Credit quality implied momentum profits for Islamic stocks." Pacific-Basin Finance Journal 42:11-23.

Narayan, Paresh Kumar, and Dinh Hoang Bach Phan. 2017. "Momentum strategies for Islamic stocks." Pacific-Basin Finance Journal 42:96-112.

Zhang, X. 2006. "Information uncertainty and stock returns." The Journal of Finance 61 (1):105-37. 
Table 1: Predictions of momentum returns based on behavioral models. Panel A (B) shows the predictions of momentum returns based on time-series (cross-sectional) implication of DHS (Daniel, Hirshleifer, and Subrahmanyam 1998), BSV (Barberis, Shleifer, and Vishny 1998) and HS (Hong and Stein 1999) models. Nonnegative (negative) market returns over months $t-11$ to $t$ and subsequent market returns over month $t+1$ are used to define UP/UP, UP/DN, DN/UP and DN/DN market states. If lagged market returns and subsequent market returns are non-negative (negative), market state is UP/UP (DN/DN). If lagged market returns are non-negative (negative), and subsequent market returns are negative (non-negative), then the market state is defined as UP/DN (DN/UP). To define high and low information uncertainty $(I U)$ stocks, we sort firms into two groups based on each $I U$ proxy. We use size $(M V)$, idiosyncratic volatility $(I V)$, turnover (TOVER), firm age (AGE) and volatility $(V O L)$ as $I U$ proxies.

Panel A: Momentum returns under market dynamics (time-series implication)

\begin{tabular}{|c|c|c|c|c|}
\hline Model & UP/UP & UP/DN & DN/UP & DN/DN \\
\hline DHS & High & Low & Low & High \\
\hline HS & High & Low & High & Low \\
\hline
\end{tabular}

\begin{tabular}{lcc}
\hline Panel B: Momentum returns for stocks sorted on information uncertainty (cross-sectional implication) \\
\hline Model & $\underline{\text { High IU }}$ & $\underline{\text { Low IU }}$ \\
DHS & High & Low \\
HS & High & Low \\
BSV & High & Low \\
\hline
\end{tabular}




\section{Table 2: Descriptive statistics}

This table reports the summary statistics of monthly average values of the stock returns, price and market capitalization $(M V)$ of Sharia-compliant (Islamic) and non-Sharia compliant (Non-Islamic) stocks. The summary statistics are computed over the period of January 1991 to December 2014.

\begin{tabular}{llllllll}
\hline \multicolumn{2}{l}{ Panel A. Summary statistics } & & & & & & \\
\hline Type & Variable & $\mathrm{N}$ & Mean & Std Dev & Median & Maximum & Minimum \\
\hline \multirow{2}{*}{ Return } & Islamic & 288 & 1.47 & 10.18 & 0.80 & 63.86 & -36.74 \\
& Non-Islamic & 288 & 1.38 & 10.14 & 0.54 & 55.69 & -31.69 \\
\multirow{2}{*}{ Price } & Islamic & 288 & 2.47 & 1.51 & 1.76 & 6.8 & 0.92 \\
& Non-Islamic & 288 & 2.68 & 1.46 & 2.04 & 6.87 & 1.11 \\
\multirow{2}{*}{$M V$} & Islamic & 288 & 974 & 388 & 898 & 1945 & 296 \\
& Non-Islamic & 288 & 1138 & 560 & 990 & 2739 & 300 \\
\hline
\end{tabular}

\begin{tabular}{|c|c|c|c|c|c|c|c|}
\hline \multicolumn{8}{|c|}{ Panel B. Correlations } \\
\hline \multirow[b]{2}{*}{ Type } & \multirow[b]{2}{*}{ Variable } & \multicolumn{2}{|c|}{ Return } & \multicolumn{2}{|r|}{ Price } & \multicolumn{2}{|r|}{$M V$} \\
\hline & & Islamic & Non-Islamic & Islamic & Non-Islamic & Islamic & Non-Islamic \\
\hline \multirow{2}{*}{ Return } & Islamic & 1.00 & & & & & \\
\hline & Non-Islamic & 0.98 & 1.00 & & & & \\
\hline \multirow{2}{*}{ Price } & Islamic & 0.10 & 0.09 & 1.00 & & & \\
\hline & Non-Islamic & 0.09 & 0.08 & 0.96 & 1.00 & & \\
\hline \multirow{2}{*}{$M V$} & Islamic & 0.10 & 0.08 & 0.20 & 0.26 & 1.00 & \\
\hline & Non-Islamic & 0.06 & 0.04 & -0.02 & 0.06 & 0.92 & 1.00 \\
\hline
\end{tabular}




\section{Table 3: Cross-Sectional and Time-Series Momentum Returns}

This table presents cross-sectional (CS) and time-series (TS) momentum returns of Sharia compliant (Islamic) and non-compliant (Non-Islamic) stocks. For CS-MOM, we sort stocks into two equal-weighted portfolios based on their returns from month $t-6$ to $t-1$ in excess of the cross-sectional average (see equation 2). For TSMOM, we sort stocks based on their returns from month $t-6$ to $t-1$ in excess of risk-free rate (see equation 3 ). We keep these portfolios for 6-months, $t+1$ to $t+6$. Following Jegadeesh and Titman (1993), we use overlapping portfolios. We report monthly average returns of loser (L), Winner (W), momentum returns (W-L), CAPM- and Fama-French adjusted momentum returns. All the returns are reported in percent and $t$-statistics provided in parenthesis. The $* * *, * *$, and $*$ denote significance of raw (CS- and TS-MOM) and risk-adjusted (CAPM and FF) momentum returns at the 1 percent, 5 percent, and 10 percent levels, respectively. The sample period ranges from January 1990 to December 2014.

\begin{tabular}{lccc}
\hline Panel A: CS momentum returns & & & \\
\hline & Islamic (A) & Non-Islamic (B) & A-B \\
L & 0.84 & 0.79 & 0.05 \\
& $(1.34)$ & $(1.22)$ & $(0.06)$ \\
W & 0.99 & 0.95 & 0.04 \\
& $(1.80)$ & $(1.76)$ & $(0.05)$ \\
CS-MOM & 0.15 & 0.16 & -0.01 \\
& $(0.74)$ & $(0.75)$ & $(-0.05)$ \\
CAPM & 0.20 & 0.21 & -0.02 \\
& $(1.05)$ & $(1.06)$ & $(-0.06)$ \\
FF & 0.13 & 0.17 & -0.03 \\
& $(0.75)$ & $(0.88)$ & $(-0.13)$ \\
\hline Panel B: TS momentum returns & & & \\
\hline & Islamic (A) & & A-B \\
L & 0.55 & Non-Islamic (B) & 0.10 \\
W & $(0.68)$ & 0.45 & $(0.09)$ \\
& 1.28 & $(0.56)$ & -0.01 \\
TS-MOM & $(2.18)$ & 1.29 & $(-0.01)$ \\
CAPM & 0.73 & $(2.14)$ & -0.11 \\
FF & $(0.92)$ & 0.84 & $(-0.09)$ \\
& 0.95 & $(1.03)$ & -0.11 \\
& $(1.22)$ & 1.06 & $(-0.1)$ \\
\end{tabular}




\section{Table 4: Market Dynamics, Cross-Sectional and Time-Series Momentum returns}

This table presents cross-sectional (CS) and time-series (TS) momentum returns of Sharia compliant (Islamic) and non-compliant (Non-Islamic) stocks sorted on lagged and subsequent market returns. Lagged market returns over months $t-11$ to $t$ and subsequent market returns over month $t+1$ are used to define market states. If both lagged and subsequent market returns are non-negative (negative), market dynamics is described as UP/UP (DN/DN). If lagged market returns are non-negative (negative), and subsequent market returns are negative (nonnegative), then the market dynamics is described as UP/DN (DN/UP). For CS-MOM, we sort stocks into two equal-weighted portfolios based on their returns from month $t-6$ to $t-1$ in excess of the cross-sectional average (see equation 2). For TS-MOM, we sort stocks based on their returns from month $t-6$ to $t$ - 1 in excess of risk-free rate (see equation 3). We keep these portfolios for 6-months, $t+1$ to $t+6$. Following Jegadeesh and Titman (1993), we use overlapping portfolios. We report monthly average returns of loser $(\mathrm{L})$, Winner $(\mathrm{W})$, momentum returns (W-L), CAPM- and Fama-French adjusted momentum returns. All the returns are reported in percent and $t$ statistics provided in parenthesis. The $* * *, * *$, and $*$ denote significance of raw (CS- and TS-MOM) and riskadjusted (CAPM and FF) momentum returns at the 1 percent, 5 percent, and 10 percent levels, respectively. The sample period ranges from January 1990 to December 2014.

\begin{tabular}{|c|c|c|c|c|c|c|}
\hline \multicolumn{7}{|c|}{ Panel A: CS momentum returns following 12-month lagged and subsequent market turns } \\
\hline & \multicolumn{3}{|c|}{ Subsequent UP } & \multicolumn{3}{|c|}{ Subsequent DN } \\
\hline & Islamic (A) & Non-Islamic (B) & A-B & Islamic (A) & Non-Islamic (B) & A-B \\
\hline \multicolumn{7}{|c|}{ Past UP market } \\
\hline $\mathrm{N}$ & 119 & 119 & & 84 & 84 & \\
\hline \multirow[t]{2}{*}{$\mathrm{L}$} & 4.48 & 4.54 & & -3.89 & -4.38 & \\
\hline & $(7.22)$ & $(7.20)$ & & $(-6.76)$ & $(-7.47)$ & \\
\hline \multirow[t]{2}{*}{$\mathrm{W}$} & 5.10 & 4.99 & & -3.68 & -3.96 & \\
\hline & (8.37) & (8.07) & & $(-5.70)$ & $(-6.55)$ & \\
\hline \multirow[t]{2}{*}{ CS-MOM } & $0.62 * * *$ & $0.45 *$ & 0.17 & 0.24 & $0.42 * *$ & -0.18 \\
\hline & $(2.74)$ & $(1.85)$ & $(0.52)$ & $(0.99)$ & $(2.23)$ & $(1.22)$ \\
\hline \multirow[t]{2}{*}{ CAPM } & $1.15 * * *$ & $0.95 * * *$ & 0.20 & -0.40 & -0.17 & -0.23 \\
\hline & $(5.15)$ & $(3.78)$ & $(0.61)$ & $(-1.69)$ & $(-0.82)$ & $(-0.68)$ \\
\hline \multirow[t]{2}{*}{$\mathrm{FF}$} & $1.08 * * *$ & $0.92 * * *$ & 0.16 & -0.37 & -0.11 & -0.26 \\
\hline & $(4.43)$ & $(3.53)$ & $(0.46)$ & $(-1.48)$ & $(-0.51)$ & $(-0.67)$ \\
\hline \multicolumn{7}{|c|}{ Past DN market } \\
\hline$\overline{\mathrm{N}}$ & 46 & 46 & & 39 & 39 & \\
\hline \multirow[t]{2}{*}{$\mathrm{L}$} & 8.59 & 9.27 & & -9.20 & -9.61 & \\
\hline & $(3.70)$ & $(3.95)$ & & $(-5.60)$ & $(-6.19)$ & \\
\hline \multirow[t]{2}{*}{$\mathrm{W}$} & 6.41 & 6.79 & & -7.87 & -7.63 & \\
\hline & (3.79) & $(4.15)$ & & $(-5.73)$ & $(-6.02)$ & \\
\hline \multirow[t]{2}{*}{ CS-MOM } & $-2.18 * *$ & $-2.48 * * *$ & 0.31 & $1.34 * *$ & $1.97 * * *$ & -0.63 \\
\hline & $(-2.61)$ & $(-2.66)$ & $(0.24)$ & $(2.46)$ & (3.64) & $(-0.83)$ \\
\hline \multirow[t]{2}{*}{ CAPM } & $-1.12 *$ & $-1.42 *$ & 0.30 & $1.03 * *$ & $1.27 * *$ & -0.24 \\
\hline & $(-1.67)$ & $(-1.78)$ & $(0.27)$ & (2.04) & $(2.42)$ & $(-0.82)$ \\
\hline \multirow[t]{2}{*}{ FF } & $-1.48 * *$ & $-1.76 * *$ & 0.28 & $1.08 * *$ & $1.31 * *$ & -0.23 \\
\hline & $(-2.33)$ & $(-2.34)$ & $(0.28)$ & $(2.10)$ & (2.64) & $(-0.49)$ \\
\hline
\end{tabular}


Table 4: Continued

\begin{tabular}{|c|c|c|c|c|c|c|}
\hline \multicolumn{7}{|c|}{ Panel B: TS momentum returns following 12-month lagged and subsequent market turns } \\
\hline & \multicolumn{3}{|c|}{ Subsequent UP } & \multicolumn{3}{|c|}{ Subsequent DN } \\
\hline & Islamic (A) & Non-Islamic (B) & A-B & $\operatorname{Islamic}(\mathrm{A})$ & Non-Islamic (B) & A-B \\
\hline \multicolumn{7}{|c|}{ Past UP market } \\
\hline $\mathrm{N}$ & 119 & 119 & & 84 & 84 & \\
\hline \multirow[t]{2}{*}{$\mathrm{L}$} & 3.12 & 3.05 & & -2.81 & -3.31 & \\
\hline & $(6.61)$ & $(6.49)$ & & $(-5.99)$ & $(-6.88)$ & \\
\hline \multirow[t]{2}{*}{$\mathrm{W}$} & 6.45 & 6.49 & & -4.75 & -5.03 & \\
\hline & $(7.23)$ & $(6.82)$ & & $(-5.25)$ & $(-5.74)$ & \\
\hline \multirow[t]{2}{*}{ TS-MOM } & $3.33^{* * *}$ & $3.44 * * *$ & -0.10 & $-1.94 * *$ & $-1.72 * *$ & -0.22 \\
\hline & $(4.39)$ & $(3.97)$ & $(-0.18)$ & $(-2.44)$ & $(-2.20)$ & $(-0.19)$ \\
\hline \multirow[t]{2}{*}{ CAPM } & $4.89 * * *$ & $5.00 * * *$ & -0.10 & $-3.68 * * *$ & $-3.46 * * *$ & -0.22 \\
\hline & $(5.68)$ & $(5.15)$ & $(-0.08)$ & $(-4.05)$ & $(-3.86)$ & $(-0.17)$ \\
\hline \multirow[t]{2}{*}{$\mathrm{FF}$} & $4.06 * * *$ & $4.23 * * *$ & -0.17 & $-3.74 * * *$ & $-3.49 * * *$ & -0.25 \\
\hline & $(4.18)$ & $(3.99)$ & $(-0.12)$ & $(-4.03)$ & $(-3.86)$ & $(-0.19)$ \\
\hline \multicolumn{7}{|c|}{ Past DN market } \\
\hline$\overline{\mathrm{N}}$ & 46 & 46 & & 39 & 39 & \\
\hline \multirow[t]{2}{*}{$\mathrm{L}$} & 11.55 & 12.51 & & -13.01 & -13.60 & \\
\hline & $(3.26)$ & $(3.59)$ & & $(-5.32)$ & $(-5.91)$ & \\
\hline \multirow[t]{2}{*}{$\mathrm{W}$} & 3.45 & 3.55 & & -4.06 & -3.63 & \\
\hline & $(2.96)$ & $(2.96)$ & & $(-4.16)$ & $(-4.05)$ & \\
\hline \multirow[t]{2}{*}{ TS-MOM } & $-8.10 * *$ & $-8.96 * *$ & 0.86 & $8.95 * * *$ & $9.97 * * *$ & -1.02 \\
\hline & $(-2.33)$ & $(-2.62)$ & $(0.18)$ & $(4.00)$ & $(4.71)$ & $(-0.33)$ \\
\hline \multirow[t]{2}{*}{ CAPM } & -5.08 & $-5.94 *$ & 0.86 & $5.51 * * *$ & $6.53 * * *$ & -1.02 \\
\hline & $(-1.57)$ & $(-1.88)$ & $(0.19)$ & $(2.79)$ & $(3.54)$ & $(-0.38)$ \\
\hline \multirow[t]{2}{*}{$\mathrm{FF}$} & $-5.78^{*}$ & $-6.55 * *$ & 0.77 & $4.53 * *$ & $5.50 * * *$ & -0.98 \\
\hline & $(-1.95)$ & $(-2.20)$ & $(0.18)$ & $(2.36)$ & $(3.00)$ & $(-0.37)$ \\
\hline
\end{tabular}




\section{Table 5: Information Uncertainty and Cross-Sectional Momentum returns}

This table presents cross-sectional (CS) momentum returns of Sharia compliant (Islamic) and non-compliant (Non-Islamic) stocks sorted on information uncertainty proxies. At the beginning of each month $t+1$, we sort firms in two groups based on each $I U$ proxy and further into two groups based on their returns from month $t-6$ to $t-1$ in excess of the cross-sectional average (see equation 2). We use size $(M V)$, idiosyncratic volatility $(I V)$, turnover $(T O V E R)$, firm age $(A G E)$ and volatility $(V O L)$ as proxies for information uncertainty. We keep these portfolios for 6-months, $t+1$ to $t+6$. Following Jegadeesh and Titman (1993), we use overlapping portfolios. We report monthly average momentum returns of low (MOM-L), high (MOM-H) IU portfolios, and also the difference (MOMH-MOML) in momentum returns between high and low $I U$ portfolios. All the returns are reported in percent and $t$-statistics provided in parenthesis. The $* * *, * *$, and $*$ denote significance of raw (CS-MOM) and risk-adjusted (CAPM and FF) momentum returns at the 1 percent, 5 percent, and 10 percent levels, respectively. The sample period ranges from January 1990 to December 2014.

\begin{tabular}{lccc}
\hline \multicolumn{2}{l}{ Panel A: CS momentum returns sorted on $M V$} & & \\
\hline \multirow{2}{*}{ MOM-L } & Islamic (A) & Non-Islamic (B) & A-B \\
& $0.37^{*}$ & 0.18 & 0.19 \\
\multirow{2}{*}{ MOM-H } & $(1.92)$ & $(0.80)$ & $(0.82)$ \\
& 0.06 & 0.26 & -0.19 \\
MOMH- MOML & $(0.34)$ & $(1.22)$ & $(-0.68)$ \\
& -0.31 & 0.07 & $-0.38^{*}$ \\
\end{tabular}

\begin{tabular}{lccc}
\hline \multicolumn{2}{l}{ Panel B: CS momentum returns sorted on $I V$} & & \\
\hline \multirow{2}{*}{ MOM-L } & Islamic (A) & Non-Islamic (B) & A-B \\
& 0.25 & 0.21 & 0.04 \\
\multirow{2}{*}{ MOM-H } & $(1.23)$ & $(1.03)$ & $(0.15)$ \\
& 0.08 & 0.15 & -0.07 \\
\multirow{2}{*}{ MOMH- MOML } & $(0.42)$ & $(0.71)$ & $(-0.25)$ \\
& -0.17 & -0.06 & -0.12 \\
\end{tabular}

\begin{tabular}{lccc}
\hline \multicolumn{2}{l}{ Panel C: CS momentum returns sorted on TOVER } & & \\
\hline \multirow{2}{*}{ MOM-L } & Islamic (A) & Non-Islamic (B) & A-B \\
& 0.21 & 0.24 & -0.03 \\
\multirow{2}{*}{ MOM-H } & $(1.19)$ & $(1.35)$ & $(-0.11)$ \\
& 0.25 & 0.19 & 0.06 \\
\multirow{2}{*}{ MOMH- MOML } & $(1.14)$ & $(0.81)$ & $(0.19)$ \\
& 0.03 & -0.06 & 0.09 \\
\end{tabular}

\begin{tabular}{lccc}
\hline \multicolumn{2}{l}{ Panel D: CS momentum returns sorted on $A G E$} & & \\
\hline \multirow{2}{*}{ MOM-L } & Islamic (A) & Non-Islamic (B) & A-B \\
& 0.12 & 0.10 & 0.02 \\
MOM-H & $(0.53)$ & $(0.42)$ & $(0.06)$ \\
& 0.09 & 0.18 & -0.09 \\
\multirow{2}{*}{ MOMH- MOML } & $(0.55)$ & $(0.85)$ & $(-0.33)$ \\
& -0.03 & 0.08 & -0.11 \\
\end{tabular}

Panel E: CS momentum returns sorted on $V O L$

\begin{tabular}{lccc}
\hline & Islamic (A) & Non-Islamic (B) & A-B \\
\hline \multirow{2}{*}{ MOM-L } & 0.28 & 0.18 & 0.10 \\
\multirow{2}{*}{ MOM-H } & $(1.40)$ & $(0.88)$ & $(0.35)$ \\
& 0.02 & 0.11 & -0.08 \\
MOMH- MOML & $(0.13)$ & $(0.51)$ & $(-0.3)$ \\
& -0.25 & -0.07 & -0.18 \\
\end{tabular}




\section{Table 6: Information Uncertainty and Time-Series Momentum returns}

This table presents time-series (TS) momentum returns of Sharia compliant (Islamic) and non-compliant (NonIslamic) stocks sorted on information uncertainty proxies. At the beginning of each month $t+1$, we sort firms in two groups based on each $I U$ proxy and further into two groups based on their returns from month $t-6$ to $t-1$ in excess of risk-free rate (see equation 3). We use size $(M V)$, idiosyncratic volatility $(I V)$, turnover (TOVER), firm age $(A G E)$ and volatility $(V O L)$ as proxies for information uncertainty. We keep these portfolios for 6-months, $t+1$ to $t+6$. Following Jegadeesh and Titman (1993), we use overlapping portfolios. We report monthly average momentum returns of low (MOM-L), high (MOM-H) IU portfolios, and also the difference (MOMH-MOML) in momentum returns between high and low $I U$ portfolios. All the returns are reported in percent and $t$-statistics provided in parenthesis. The $* * *, * *$, and $*$ denote significance of raw (TS-MOM) and risk-adjusted (CAPM and FF) momentum returns at the 1 percent, 5 percent, and 10 percent levels, respectively. The sample period ranges from January 1990 to December 2014.

\begin{tabular}{lccc}
\hline \multicolumn{2}{l}{ Panel A: TS momentum returns sorted on $M V$} & & \\
\hline \multirow{2}{*}{ MOM-L } & Islamic (A) & Non-Islamic (B) & A-B \\
& $1.23^{*}$ & 1.02 & 0.21 \\
\multirow{2}{*}{ MOM-H } & $(1.93)$ & $(1.47)$ & $(0.22)$ \\
& 0.92 & 1.19 & -0.27 \\
MOMH- MOML & $(1.09)$ & $(1.36)$ & $(-0.22)$ \\
& -0.31 & 0.17 & -0.48 \\
\end{tabular}

\begin{tabular}{lccc}
\hline \multicolumn{2}{l}{ Panel B: TS momentum returns sorted on $I V$} & & \\
\hline \multirow{2}{*}{ MOM-L } & Islamic (A) & Non-Islamic (B) & A-B \\
& 0.92 & 0.88 & 0.03 \\
\multirow{2}{*}{ MOM-H } & $(1.28)$ & $(1.23)$ & $(0.03)$ \\
& 0.52 & 0.68 & -0.17 \\
\multirow{2}{*}{ MOMH- MOML } & $(0.54)$ & $(0.71)$ & $(-0.12)$ \\
& -0.40 & -0.20 & -0.20 \\
\end{tabular}

\begin{tabular}{lccc}
\hline \multicolumn{2}{l}{ Panel C: TS momentum returns sorted on TOVER } & & \\
\hline \multirow{2}{*}{ MOM-L } & Islamic (A) & Non-Islamic (B) & A-B \\
& 0.67 & 0.80 & -0.13 \\
\multirow{2}{*}{ MOM-H } & $(1.15)$ & $(1.13)$ & $(-0.14)$ \\
& 0.68 & 0.90 & -0.21 \\
\multirow{2}{*}{ MOMH- MOML } & $(0.76)$ & $(0.99)$ & $(-0.17)$ \\
& 0.01 & 0.09 & -0.08 \\
\end{tabular}

\begin{tabular}{lccc}
\hline \multicolumn{2}{l}{ Panel D: TS momentum returns sorted on $A G E$} & & \\
\hline \multirow{2}{*}{ MOM-L } & Islamic (A) & Non-Islamic (B) & A-B \\
& 0.77 & 0.80 & -0.03 \\
\multirow{2}{*}{ MOM-H } & $(0.95)$ & $(0.96)$ & $(-0.10)$ \\
& 0.55 & 0.80 & -0.25 \\
\multirow{2}{*}{ MOMH- MOML } & $(0.81)$ & $(1.04)$ & $(-0.76)$ \\
& -0.22 & -0.00 & -0.22 \\
\end{tabular}

Panel E: TS momentum returns sorted on $V O L$

\begin{tabular}{lccc}
\hline & Islamic (A) & Non-Islamic (B) & A-B \\
\hline \multirow{2}{*}{ MOM-L } & 0.91 & 0.98 & -0.07 \\
\multirow{2}{*}{ MOM-H } & $(1.35)$ & $(1.47)$ & $(-0.07)$ \\
& 0.71 & 0.85 & -0.14 \\
\multirow{2}{*}{ MOMH- MOML } & $(0.72)$ & $(0.85)$ & $(-0.10)$ \\
& -0.20 & -0.13 & -0.07 \\
\end{tabular}




\section{Table 7: Information Uncertainty, Market Dynamics and Cross-Sectional Momentum Returns}

This table presents cross-sectional (CS) momentum returns of Sharia compliant (Islamic) and non-compliant (Non-Islamic) stocks sorted on lagged and subsequent market returns, and information uncertainty proxies. Lagged market returns over months $t-11$ to $t$ and subsequent market returns over month $t+1$ are used to define market states. If both lagged and subsequent market returns are non-negative (negative), the market dynamics is described as UP/UP (DN/DN). If lagged market returns are non-negative (negative), and subsequent market returns are negative (non-negative), then the market dynamics is described as UP/DN (DN/UP). At the beginning of each month $t+1$, we sort firms in two groups based on each $I U$ proxy and further into two groups based on their returns from month $t-6$ to $t-1$ in excess of the cross-sectional average (see equation 2). We use size $(M V)$, idiosyncratic volatility $(I V)$, turnover $(T O V E R)$, firm age $(A G E)$ and volatility $(V O L)$ as proxies for information uncertainty. We keep these portfolios for 6-months, $t+1$ to $t+6$. Following Jegadeesh and Titman (1993), we use overlapping portfolios. We report monthly average momentum returns of low (MOM-L), high (MOM-H) IU portfolios, and also the difference (MOMH-MOML) in momentum returns between high and low $I U$ portfolios. All the returns are reported in percent and $t$-statistics provided in parenthesis. The $* * *, * *$, and $*$ denote significance of raw (CS-MOM) and risk-adjusted (CAPM and FF) momentum returns at the 1 percent, 5 percent, and 10 percent levels, respectively. The sample period ranges from January 1990 to December 2014.

\begin{tabular}{|c|c|c|c|c|c|c|}
\hline \multicolumn{7}{|c|}{ Panel A: CS momentum returns sorted on market dynamics and $M V$} \\
\hline & \multicolumn{3}{|c|}{$\underline{\text { Subsequent UP }}$} & \multicolumn{3}{|c|}{ Subsequent DN } \\
\hline & Islamic (A) & Non-Islamic (B) & A-B & Islamic $(\mathrm{A})$ & Non-Islamic (B) & A-B \\
\hline \multicolumn{7}{|l|}{ Past UP market } \\
\hline MOM-L & $\begin{array}{c}0.85^{* * * *} \\
(4.26)\end{array}$ & $\begin{array}{c}0.34 \\
(1.61)\end{array}$ & $\begin{array}{l}0.51 * \\
(1.77)\end{array}$ & $\begin{array}{l}0.40 * \\
(1.80)\end{array}$ & $\begin{array}{c}0.39 * * * \\
(1.88)\end{array}$ & $\begin{array}{c}0.01 \\
(0.01)\end{array}$ \\
\hline MOM-H & $\begin{array}{c}0.42 \\
(1.37)\end{array}$ & $\begin{array}{l}0.53 * \\
(1.75)\end{array}$ & $\begin{array}{l}-0.11 \\
(-0.27)\end{array}$ & $\begin{array}{c}0.21 \\
(0.89)\end{array}$ & $\begin{array}{c}0.54 * * \\
(2.54)\end{array}$ & $\begin{array}{c}-0.33 \\
(-1.04)\end{array}$ \\
\hline MOMH- MOML & $\begin{array}{c}-0.43 \\
(-1.53)\end{array}$ & $\begin{array}{c}0.19 \\
(0.82)\end{array}$ & $\begin{array}{c}-0.62 \\
(-1.65)\end{array}$ & $\begin{array}{c}-0.19 \\
(-0.83)\end{array}$ & $\begin{array}{c}0.17 \\
(0.79)\end{array}$ & $\begin{array}{c}-0.34 \\
(-1.07)\end{array}$ \\
\hline \multicolumn{7}{|l|}{ Past DN market } \\
\hline MOM-L & $\begin{array}{c}-1.82 * * \\
(-2.02)\end{array}$ & $\begin{array}{c}-2.38 * * \\
(-2.25)\end{array}$ & $\begin{array}{c}0.56 \\
(0.41)\end{array}$ & $\begin{array}{c}1.88 * * * \\
(3.70)\end{array}$ & $\begin{array}{c}2.44 * * * \\
(4.54)\end{array}$ & $\begin{array}{c}-0.58 \\
(-0.79)\end{array}$ \\
\hline MOM-H & $\begin{array}{c}-1.74 * * \\
(-2.68)\end{array}$ & $\begin{array}{c}-2.24 * * * \\
(-2.83)\end{array}$ & $\begin{array}{c}0.50 \\
(0.49)\end{array}$ & $\begin{array}{l}1.13 * * \\
(2.49)\end{array}$ & $\begin{array}{c}1.82 * * * \\
(4.03)\end{array}$ & $\begin{array}{c}-0.69 \\
(-1.07)\end{array}$ \\
\hline MOMH- MOML & $\begin{array}{c}0.08 \\
(0.15) \\
\end{array}$ & $\begin{array}{c}0.14 \\
(0.24) \\
\end{array}$ & $\begin{array}{c}-0.06 \\
(-0.07)\end{array}$ & $\begin{array}{l}-0.75^{*} \\
(-1.68) \\
\end{array}$ & $\begin{array}{c}-0.60 \\
(-1.55) \\
\end{array}$ & $\begin{array}{c}-0.11 \\
(-0.19) \\
\end{array}$ \\
\hline \multicolumn{7}{|c|}{ Panel B: CS momentum returns sorted on market dynamics and $I V$} \\
\hline & \multicolumn{3}{|c|}{ Subsequent UP } & \multicolumn{3}{|c|}{ Subsequent DN } \\
\hline & Islamic $(\mathrm{A})$ & Non-Islamic (B) & A-B & Islamic (A) & Non-Islamic (B) & $\mathrm{A}-\mathrm{B}$ \\
\hline \multicolumn{7}{|l|}{ Past UP market } \\
\hline MOM-L & $\begin{array}{c}0.65 * * * \\
(2.89)\end{array}$ & $\begin{array}{c}0.34 \\
(1.38)\end{array}$ & $\begin{array}{c}0.31 \\
(0.92)\end{array}$ & $\begin{array}{c}0.52 * * \\
(2.46)\end{array}$ & $\begin{array}{c}0.61 * * * \\
(3.07)\end{array}$ & $\begin{array}{c}-0.09 \\
(-0.30)\end{array}$ \\
\hline MOM-H & $\begin{array}{c}0.29 \\
(1.20)\end{array}$ & $\begin{array}{c}0.29 \\
(1.04)\end{array}$ & $\begin{array}{c}-0.01 \\
(-0.01)\end{array}$ & $\begin{array}{c}0.35 \\
(1.52)\end{array}$ & $\begin{array}{c}0.58 * * * \\
(2.83)\end{array}$ & $\begin{array}{c}-0.23 \\
(-0.74)\end{array}$ \\
\hline MOMH- MOML & $\begin{array}{c}-0.36 \\
(-1.61)\end{array}$ & $\begin{array}{c}-0.05 \\
(-0.19)\end{array}$ & $\begin{array}{c}-0.31 \\
(-0.87)\end{array}$ & $\begin{array}{c}-0.17 \\
(-0.66)\end{array}$ & $\begin{array}{c}-0.03 \\
(-0.15)\end{array}$ & $\begin{array}{c}-0.14 \\
(-0.40)\end{array}$ \\
\hline Past DN market & & & & & & \\
\hline MOM-L & $\begin{array}{c}-2.54 * * * \\
(-2.84)\end{array}$ & $\begin{array}{c}-2.01 * * \\
(-2.28)\end{array}$ & $\begin{array}{c}-0.53 \\
(-0.42)\end{array}$ & $\begin{array}{c}1.76 * * * \\
(3.72)\end{array}$ & $\begin{array}{c}1.56 * * * \\
(3.21)\end{array}$ & $\begin{array}{c}0.20 \\
(0.30)\end{array}$ \\
\hline MOM-H & $\begin{array}{c}-1.58 * * \\
(-2.17)\end{array}$ & $\begin{array}{c}-2.16^{* *} \\
(-2.44)\end{array}$ & $\begin{array}{c}0.58 \\
(0.50)\end{array}$ & $\begin{array}{c}0.83 \\
(1.37)\end{array}$ & $\begin{array}{l}1.54 * * \\
(2.69)\end{array}$ & $\begin{array}{c}-0.71 \\
(-0.85)\end{array}$ \\
\hline MOMH- MOML & $\begin{array}{l}0.96^{*} \\
(1.89)\end{array}$ & $\begin{array}{c}-0.15 \\
(-0.32)\end{array}$ & $\begin{array}{c}1.11 \\
(1.60)\end{array}$ & $\begin{array}{c}-0.93 * * \\
(-2.39)\end{array}$ & $\begin{array}{c}-0.02 \\
(-0.04)\end{array}$ & $\begin{array}{l}-0.91 * \\
(-1.68)\end{array}$ \\
\hline
\end{tabular}


Table 7: Continued

\begin{tabular}{|c|c|c|c|c|c|c|}
\hline \multicolumn{7}{|c|}{ Panel C: CS momentum returns sorted on market dynamics and TOVER } \\
\hline & \multicolumn{3}{|c|}{ Subsequent UP } & \multicolumn{3}{|c|}{ Subsequent DN } \\
\hline & $\operatorname{Islamic}(\mathrm{A})$ & Non-Islamic (B) & A-B & Islamic (A) & Non-Islamic (B) & A-B \\
\hline \multicolumn{7}{|l|}{ Past UP market } \\
\hline MOM-L & $\begin{array}{c}0.65^{* * * *} \\
(2.86)\end{array}$ & $\begin{array}{c}0.35 \\
(1.43)\end{array}$ & $\begin{array}{c}0.30 \\
(0.91)\end{array}$ & $\begin{array}{c}0.03 \\
(0.13)\end{array}$ & $\begin{array}{c}0.48 * * \\
(2.59)\end{array}$ & $\begin{array}{l}-0.45 \\
(-1.53)\end{array}$ \\
\hline MOM-H & $\begin{array}{l}0.59 * * \\
(2.37)\end{array}$ & $\begin{array}{c}0.34 \\
(1.26)\end{array}$ & $\begin{array}{c}0.25 \\
(0.66)\end{array}$ & $\begin{array}{l}0.61 * * \\
(2.61)\end{array}$ & $\begin{array}{c}0.63 * * * \\
(2.82)\end{array}$ & $\begin{array}{l}-0.02 \\
(-0.08)\end{array}$ \\
\hline MOMH- MOML & $\begin{array}{c}-0.06 \\
(-0.19)\end{array}$ & $\begin{array}{c}-0.01 \\
(-0.02)\end{array}$ & $\begin{array}{c}-0.05 \\
(-0.14)\end{array}$ & $\begin{array}{l}0.58 * * \\
(2.15)\end{array}$ & $\begin{array}{c}0.15 \\
(0.63)\end{array}$ & $\begin{array}{c}0.43 \\
(1.20)\end{array}$ \\
\hline \multicolumn{7}{|l|}{ Past DN market } \\
\hline MOM-L & $\begin{array}{c}-1.43 * * \\
(-1.96)\end{array}$ & $\begin{array}{l}-1.68 * * \\
(-2.33)\end{array}$ & $\begin{array}{c}0.24 \\
(0.24)\end{array}$ & $\begin{array}{l}1.27 * * * \\
(2.91)\end{array}$ & $\begin{array}{c}1.72 * * * \\
(3.87)\end{array}$ & $\begin{array}{l}-0.45 \\
(-0.73)\end{array}$ \\
\hline MOM-H & $\begin{array}{c}-2.15 * * * \\
(-2.27)\end{array}$ & $\begin{array}{c}-2.61 * * * \\
(-2.63)\end{array}$ & $\begin{array}{c}0.46 \\
(0.33)\end{array}$ & $\begin{array}{l}1.30 * * \\
(2.31)\end{array}$ & $\begin{array}{l}2.11 * * * \\
(3.81)\end{array}$ & $\begin{array}{c}-0.81 \\
(-1.03)\end{array}$ \\
\hline MOMH- MOML & $\begin{array}{c}-0.72 \\
(-1.39) \\
\end{array}$ & $\begin{array}{l}-0.93 * \\
(-1.85) \\
\end{array}$ & $\begin{array}{c}0.21 \\
(0.29) \\
\end{array}$ & $\begin{array}{c}0.03 \\
(0.09) \\
\end{array}$ & $\begin{array}{c}0.39 \\
(0.90) \\
\end{array}$ & $\begin{array}{c}-0.36 \\
(-0.66) \\
\end{array}$ \\
\hline \multicolumn{7}{|c|}{ Panel D: CS momentum returns sorted on market dynamics and $A G E$} \\
\hline & \multirow{2}{*}{\multicolumn{3}{|c|}{ Islamic (A) $\frac{\text { Subsequent UP }}{\text { Non-Islamic (B) }}$}} & \multicolumn{3}{|c|}{ Subsequent DN } \\
\hline & & & & Islamic (A) & Non-Islamic (B) & A-B \\
\hline \multicolumn{7}{|l|}{ Past UP market } \\
\hline MOM-L & $\begin{array}{c}0.57 * * \\
(2.45)\end{array}$ & $\begin{array}{c}0.24 \\
(0.94)\end{array}$ & $\begin{array}{c}0.34 \\
(0.98)\end{array}$ & $\begin{array}{c}0.14 \\
(0.63)\end{array}$ & $\begin{array}{c}0.34 \\
(1.37)\end{array}$ & $\begin{array}{l}-0.20 \\
(-0.59)\end{array}$ \\
\hline MOM-H & $\begin{array}{c}0.50 * * \\
(2.41)\end{array}$ & $\begin{array}{l}0.51^{*} \\
(1.83)\end{array}$ & $\begin{array}{l}-0.01 \\
(-0.02)\end{array}$ & $\begin{array}{c}0.23 \\
(1.12)\end{array}$ & $\begin{array}{l}0.41 * * \\
(2.18)\end{array}$ & $\begin{array}{l}-0.18 \\
(-0.63)\end{array}$ \\
\hline MOMH- MOML & $\begin{array}{c}-0.07 \\
(-0.26)\end{array}$ & $\begin{array}{c}0.28 \\
(1.06)\end{array}$ & $\begin{array}{c}-0.34 \\
(-0.94)\end{array}$ & $\begin{array}{c}0.09 \\
(0.41)\end{array}$ & $\begin{array}{c}0.07 \\
(0.27)\end{array}$ & $\begin{array}{c}-0.02 \\
(-0.06)\end{array}$ \\
\hline \multicolumn{7}{|l|}{ Past DN market } \\
\hline MOM-L & $\begin{array}{c}-2.42 * * \\
(-2.34)\end{array}$ & $\begin{array}{c}-2.53 * * \\
(-2.33)\end{array}$ & $\begin{array}{c}0.11 \\
(0.07)\end{array}$ & $\begin{array}{l}1.70 * * \\
(2.65)\end{array}$ & $\begin{array}{c}2.28 * * * \\
(3.80)\end{array}$ & $\begin{array}{c}-0.58 \\
(-0.66)\end{array}$ \\
\hline MOM-H & $\begin{array}{l}-1.79 * * \\
(-2.64)\end{array}$ & $\begin{array}{l}-2.51 * * * \\
(-2.76)\end{array}$ & $\begin{array}{c}0.72 \\
(0.63)\end{array}$ & $\begin{array}{l}0.77 * \\
(1.74)\end{array}$ & $\begin{array}{c}1.87 * * * \\
(3.89)\end{array}$ & $\begin{array}{l}-1.10^{*} \\
(-1.68)\end{array}$ \\
\hline MOMH- MOML & $\begin{array}{c}0.63 \\
(1.03) \\
\end{array}$ & $\begin{array}{c}0.02 \\
(0.03) \\
\end{array}$ & $\begin{array}{c}0.61 \\
(0.71) \\
\end{array}$ & $\begin{array}{c}-0.93 * * \\
(-2.21)\end{array}$ & $\begin{array}{c}-0.41 \\
(-1.25) \\
\end{array}$ & $\begin{array}{c}-0.52 \\
(-0.98) \\
\end{array}$ \\
\hline \multicolumn{7}{|c|}{ Panel E: CS momentum returns sorted on market dynamics and $V O L$} \\
\hline & \multirow{2}{*}{\multicolumn{3}{|c|}{ Islamic (A) $\frac{\text { Subsequent UP }}{\text { Non-Islamic (B) }}$}} & \multicolumn{3}{|c|}{ Subsequent DN } \\
\hline & & & & Islamic (A) & Non-Islamic (B) & A-B \\
\hline \multicolumn{7}{|l|}{ Past UP market } \\
\hline MOM-L & $\begin{array}{c}0.68 * * * \\
(2.96)\end{array}$ & $\begin{array}{c}0.33 \\
(1.38)\end{array}$ & $\begin{array}{c}0.35 \\
(1.05)\end{array}$ & $\begin{array}{c}0.45^{* *} \\
(2.01)\end{array}$ & $\begin{array}{c}0.61 * * * \\
(3.43)\end{array}$ & $\begin{array}{l}-0.16 \\
(-0.54)\end{array}$ \\
\hline MOM-H & $\begin{array}{c}0.14 \\
(0.56)\end{array}$ & $\begin{array}{c}0.17 \\
(0.59)\end{array}$ & $\begin{array}{l}-0.02 \\
(-0.06)\end{array}$ & $\begin{array}{l}0.49 * * * \\
(2.35)\end{array}$ & $\begin{array}{l}0.65^{* * *} \\
(3.14)\end{array}$ & $\begin{array}{l}-0.16 \\
(-0.53)\end{array}$ \\
\hline MOMH- MOML & $\begin{array}{c}-0.53 * * \\
(-2.04)\end{array}$ & $\begin{array}{c}-0.16 \\
(-0.56)\end{array}$ & $\begin{array}{c}-0.37 \\
(-0.94)\end{array}$ & $\begin{array}{c}0.04 \\
(0.15)\end{array}$ & $\begin{array}{c}0.04 \\
(0.19)\end{array}$ & $\begin{array}{c}-0.00 \\
(-0.01)\end{array}$ \\
\hline \multicolumn{7}{|l|}{ Past DN market } \\
\hline MOM-L & $\begin{array}{l}-2.12 * * \\
(-2.48)\end{array}$ & $\begin{array}{c}-2.38 * * \\
(-2.71)\end{array}$ & $\begin{array}{l}0.26 \\
(0.22)\end{array}$ & $\begin{array}{c}1.49 * * * \\
(3.48)\end{array}$ & $\begin{array}{c}1.80 * * * \\
(4.10)\end{array}$ & $\begin{array}{c}-0.31 \\
(-0.51)\end{array}$ \\
\hline MOM-H & $\begin{array}{l}-1.82 * * \\
(-2.65)\end{array}$ & $\begin{array}{l}-1.83^{* *} \\
(-2.08)\end{array}$ & $\begin{array}{c}0.01 \\
(0.01)\end{array}$ & $\begin{array}{c}0.82 \\
(1.41)\end{array}$ & $\begin{array}{l}1.04 * \\
(1.89)\end{array}$ & $\begin{array}{c}-0.22 \\
(-0.28)\end{array}$ \\
\hline MOMH- MOML & $\begin{array}{c}0.30 \\
(0.59)\end{array}$ & $\begin{array}{c}0.56 \\
(0.96)\end{array}$ & $\begin{array}{c}-0.26 \\
(-0.33) \\
\end{array}$ & $\begin{array}{c}-0.67 \\
(-1.60)\end{array}$ & $\begin{array}{l}-0.76 * * \\
(-1.96) \\
\end{array}$ & $\begin{array}{c}0.09 \\
(0.16)\end{array}$ \\
\hline
\end{tabular}




\section{Table 8: Information Uncertainty, Market Dynamics and Time-Series Momentum Returns}

This table presents time-series (TS) momentum returns of Sharia compliant (Islamic) and non-compliant (NonIslamic) stocks sorted on lagged and subsequent market returns, and information uncertainty proxies. Lagged market returns over months $t$-11 to $t$ and subsequent market returns over month $t+1$ are used to define market states. If both lagged and subsequent market returns are non-negative (negative), the market dynamics is described as UP/UP (DN/DN). If lagged market returns are non-negative (negative), and subsequent market returns are negative (non-negative), then the market dynamics is described as UP/DN (DN/UP). At the beginning of each month $t+1$, we sort firms in two groups based on each $I U$ proxy and further into two groups based on their returns from month $t-6$ to $t$ - 1 in excess of the risk-free rate (see equation 3$)$. We use size $(M V)$, idiosyncratic volatility $(I V)$, turnover $(T O V E R)$, firm age $(A G E)$ and volatility $(V O L)$ as proxies for information uncertainty. We keep these portfolios for 6-months, $t+1$ to $t+6$. Following Jegadeesh and Titman (1993), we use overlapping portfolios. We report monthly average momentum returns of low (MOM-L), high (MOM-H) IU portfolios, and also the difference (MOMH-MOML) in momentum returns between high and low IU portfolios. All the returns are reported in percent and $t$-statistics provided in parenthesis. The $* * *, * *$, and $*$ denote significance of raw (TS-MOM) and risk-adjusted (CAPM and FF) momentum returns at the 1 percent, 5 percent, and 10 percent levels, respectively. The sample period ranges from January 1990 to December 2014.

\begin{tabular}{|c|c|c|c|c|c|c|}
\hline \multicolumn{7}{|c|}{ Panel A: TS momentum returns sorted on market dynamics and $M V$} \\
\hline & \multicolumn{3}{|c|}{$\underline{\text { Subsequent UP }}$} & \multicolumn{3}{|c|}{ Subsequent DN } \\
\hline & $\operatorname{Islamic}(\mathrm{A})$ & Non-Islamic (B) & A-B & $\operatorname{Islamic}(\mathrm{A})$ & Non-Islamic (B) & A-B \\
\hline \multicolumn{7}{|l|}{ Past UP market } \\
\hline MOM-L & $\begin{array}{c}3.87 * * * \\
(5.41)\end{array}$ & $\begin{array}{c}3.80 * * * \\
(5.05)\end{array}$ & $\begin{array}{c}0.07 \\
(0.06)\end{array}$ & $\begin{array}{c}-2.28 * * * \\
(-3.03)\end{array}$ & $\begin{array}{c}-2.45 * * * \\
(-3.26)\end{array}$ & $\begin{array}{c}0.17 \\
(0.16)\end{array}$ \\
\hline MOM-H & $\begin{array}{c}3.21 * * * \\
(3.12)\end{array}$ & $\begin{array}{c}3.03 * * * \\
(2.92)\end{array}$ & $\begin{array}{c}0.18 \\
(0.17)\end{array}$ & $\begin{array}{l}-1.64^{*} \\
(-1.86)\end{array}$ & $\begin{array}{c}-1.03 \\
(-1.20)\end{array}$ & $\begin{array}{l}-0.62 \\
(-0.50)\end{array}$ \\
\hline MOMH- MOML & $\begin{array}{c}-0.66 \\
(-1.28)\end{array}$ & $\begin{array}{c}-0.77 \\
(-1.57)\end{array}$ & $\begin{array}{c}0.11 \\
(0.20)\end{array}$ & $\begin{array}{c}0.63 \\
(1.44)\end{array}$ & $\begin{array}{c}1.42 * * * \\
(3.13)\end{array}$ & $\begin{array}{l}-0.79 \\
(-1.25)\end{array}$ \\
\hline \multicolumn{7}{|l|}{ Past DN market } \\
\hline MOM-L & $\begin{array}{c}-5.47 * * \\
(-2.09)\end{array}$ & $\begin{array}{c}-7.43^{* *} \\
(-2.53)\end{array}$ & $\begin{array}{c}1.96 \\
(0.50)\end{array}$ & $\begin{array}{c}8.39 * * * \\
(4.60)\end{array}$ & $\begin{array}{c}9.63 * * * \\
(5.02)\end{array}$ & $\begin{array}{c}-1.24 \\
(-0.47)\end{array}$ \\
\hline MOM-H & $\begin{array}{c}-7.80 * * \\
(-2.20)\end{array}$ & $\begin{array}{c}-8.62 * * \\
(-2.32)\end{array}$ & $\begin{array}{c}0.82 \\
(0.16)\end{array}$ & $\begin{array}{c}10.65 * * * \\
(3.56)\end{array}$ & $\begin{array}{c}11.48 * * * \\
(4.34)\end{array}$ & $\begin{array}{c}-0.83 \\
(-0.21)\end{array}$ \\
\hline MOMH- MOML & $\begin{array}{l}-2.33^{*} \\
(-1.94) \\
\end{array}$ & $\begin{array}{l}-1.18 \\
(-0.96)\end{array}$ & $\begin{array}{c}-1.14 \\
(-0.66) \\
\end{array}$ & $\begin{array}{c}2.26 \\
(1.36) \\
\end{array}$ & $\begin{array}{c}1.85 \\
(1.35) \\
\end{array}$ & $\begin{array}{c}0.41 \\
(0.19)\end{array}$ \\
\hline \multicolumn{7}{|c|}{ Panel B: TS momentum returns sorted on market dynamics and $I V$} \\
\hline & \multicolumn{3}{|c|}{ Subsequent UP } & \multicolumn{3}{|c|}{ Subsequent DN } \\
\hline & $\operatorname{Islamic}(\mathrm{A})$ & Non-Islamic (B) & $\mathrm{A}-\mathrm{B}$ & Islamic $(\mathrm{A})$ & Non-Islamic (B) & A-B \\
\hline \multicolumn{7}{|l|}{ Past UP market } \\
\hline MOM-L & $\begin{array}{c}2.98 * * * \\
(4.14)\end{array}$ & $\begin{array}{c}3.29 * * * \\
(3.65)\end{array}$ & $\begin{array}{l}-0.31 \\
(-0.3)\end{array}$ & $\begin{array}{l}-1.08 * \\
(-1.71)\end{array}$ & $\begin{array}{c}-1.27 * * \\
(-2.02)\end{array}$ & $\begin{array}{c}0.19 \\
(0.22)\end{array}$ \\
\hline MOM-H & $\begin{array}{c}4.17 * * * \\
(4.25)\end{array}$ & $\begin{array}{c}4.10 * * * \\
(4.15)\end{array}$ & $\begin{array}{c}0.07 \\
(0.05)\end{array}$ & $\begin{array}{c}-2.81 * * * \\
(-2.80)\end{array}$ & $\begin{array}{c}-2.32 * * \\
(-2.33)\end{array}$ & $\begin{array}{c}-0.49 \\
(-0.35)\end{array}$ \\
\hline MOMH- MOML & $\begin{array}{l}1.19^{*} \\
(1.78)\end{array}$ & $\begin{array}{c}0.81 \\
(1.62)\end{array}$ & $\begin{array}{c}0.38 \\
(0.48)\end{array}$ & $\begin{array}{c}-1.73 * * * \\
(-3.36)\end{array}$ & $\begin{array}{l}-1.04^{*} \\
(-1.93)\end{array}$ & $\begin{array}{c}-0.68 \\
(-0.92)\end{array}$ \\
\hline Past DN market & & & & & & \\
\hline MOM-L & $\begin{array}{c}-7.37 * * \\
(-2.35)\end{array}$ & $\begin{array}{c}-7.61 * * \\
(-2.55)\end{array}$ & $\begin{array}{c}0.25 \\
(0.06)\end{array}$ & $\begin{array}{c}9.94 * * * \\
(4.34)\end{array}$ & $\begin{array}{c}9.39 * * * \\
(4.74)\end{array}$ & $\begin{array}{c}0.54 \\
(0.18)\end{array}$ \\
\hline MOM-H & $\begin{array}{c}-9.66 * * \\
(-2.30)\end{array}$ & $\begin{array}{c}-11.27 * * \\
(-2.68)\end{array}$ & $\begin{array}{c}1.61 \\
(0.27)\end{array}$ & $\begin{array}{c}8.76 * * * \\
(3.36)\end{array}$ & $\begin{array}{c}11.10 * * * \\
(4.28)\end{array}$ & $\begin{array}{c}-2.34 \\
(-0.64)\end{array}$ \\
\hline MOMH- MOML & $\begin{array}{l}-2.29 * \\
(-1.78)\end{array}$ & $\begin{array}{c}-3.66 * * \\
(-2.20)\end{array}$ & $\begin{array}{c}1.37 \\
(0.65)\end{array}$ & $\begin{array}{c}-1.18 \\
(-0.90)\end{array}$ & $\begin{array}{c}1.71 \\
(1.39)\end{array}$ & $\begin{array}{l}-2.89 \\
(-1.61)\end{array}$ \\
\hline
\end{tabular}


Table 8: Continued

\begin{tabular}{|c|c|c|c|c|c|c|}
\hline \multicolumn{7}{|c|}{ Panel C: TS momentum returns sorted on market dynamics and TOVER } \\
\hline & \multicolumn{3}{|c|}{$\underline{\text { Subsequent UP}}$} & \multicolumn{3}{|c|}{ Subsequent DN } \\
\hline & Islamic (A) & Non-Islamic (B) & A-B & Islamic (A) & Non-Islamic (B) & A-B \\
\hline \multicolumn{7}{|l|}{ Past UP market } \\
\hline MOM-L & $\begin{array}{c}1.92 * * * \\
(3.55)\end{array}$ & $\begin{array}{l}2.55^{* * * *} \\
(3.13)\end{array}$ & $\begin{array}{l}-0.63 \\
(-0.65)\end{array}$ & $\begin{array}{l}-0.97 * \\
(-1.77)\end{array}$ & $\begin{array}{l}-0.86 \\
(-1.44)\end{array}$ & $\begin{array}{c}-0.11 \\
(-0.13)\end{array}$ \\
\hline MOM-H & $\begin{array}{c}3.59 * * * \\
(4.53)\end{array}$ & $\begin{array}{c}3.94 * * * \\
(4.17)\end{array}$ & $\begin{array}{l}-0.34 \\
(-0.28)\end{array}$ & $\begin{array}{l}-2.08 * * \\
(-2.37)\end{array}$ & $\begin{array}{c}-2.29 * * \\
(-2.44)\end{array}$ & $\begin{array}{c}0.21 \\
(0.16)\end{array}$ \\
\hline MOMH- MOML & $\begin{array}{c}1.68 * * * \\
(3.45)\end{array}$ & $\begin{array}{c}1.39 * * * \\
(2.83)\end{array}$ & $\begin{array}{c}0.29 \\
(0.42)\end{array}$ & $\begin{array}{l}-1.11 * * \\
(-2.18)\end{array}$ & $\begin{array}{c}-1.43 * * \\
(-2.60)\end{array}$ & $\begin{array}{c}0.32 \\
(0.42)\end{array}$ \\
\hline \multicolumn{7}{|l|}{ Past DN market } \\
\hline MOM-L & $\begin{array}{l}-5.84 * * \\
(-2.40)\end{array}$ & $\begin{array}{c}-7.69 * * \\
(-2.63)\end{array}$ & $\begin{array}{c}1.85 \\
(0.49)\end{array}$ & $\begin{array}{c}8.24 * * * \\
(4.53)\end{array}$ & $\begin{array}{c}9.29 * * * \\
(4.92)\end{array}$ & $\begin{array}{l}-1.05 \\
(-0.40)\end{array}$ \\
\hline MOM-H & $\begin{array}{l}-8.99 * * \\
(-2.21)\end{array}$ & $\begin{array}{l}-9.61 * * \\
(-2.55)\end{array}$ & $\begin{array}{c}0.62 \\
(0.11)\end{array}$ & $\begin{array}{c}9.37 * * * \\
(4.05)\end{array}$ & $\begin{array}{l}11.12 * * * \\
(4.77)\end{array}$ & $\begin{array}{l}-1.75 \\
(-0.53)\end{array}$ \\
\hline MOMH- MOML & $\begin{array}{l}-3.15^{*} \\
(-1.69)\end{array}$ & $\begin{array}{l}-1.92 * \\
(-1.90)\end{array}$ & $\begin{array}{c}-1.23 \\
(-0.58) \\
\end{array}$ & $\begin{array}{c}1.13 \\
(1.08) \\
\end{array}$ & $\begin{array}{l}1.83 * * \\
(2.59)\end{array}$ & $\begin{array}{c}-0.70 \\
(-0.56) \\
\end{array}$ \\
\hline \multicolumn{7}{|c|}{ Panel D: TS momentum returns sorted on market dynamics and $A G E$} \\
\hline & \multirow{2}{*}{\multicolumn{3}{|c|}{ Islamic (A) $\frac{\text { Subsequent UP }}{\text { Non-Islamic (B) }}$}} & \multicolumn{3}{|c|}{ Subsequent DN } \\
\hline & & & & $\operatorname{Islamic}(\mathrm{A})$ & Non-Islamic (B) & A-B \\
\hline \multicolumn{7}{|l|}{ Past UP market } \\
\hline MOM-L & $\begin{array}{c}3.42 * * * \\
(4.24)\end{array}$ & $\begin{array}{c}3.57 * * * \\
(3.96)\end{array}$ & $\begin{array}{l}-0.15 \\
(-0.12)\end{array}$ & $\begin{array}{c}-1.97 * * \\
(-2.43)\end{array}$ & $\begin{array}{c}-1.97 * * \\
(-2.40)\end{array}$ & $\begin{array}{l}-0.15 \\
(0.01)\end{array}$ \\
\hline MOM-H & $\begin{array}{c}2.88 * * * \\
(4.43)\end{array}$ & $\begin{array}{l}3.08 * * * \\
(3.73)\end{array}$ & $\begin{array}{l}-0.20 \\
(-0.19)\end{array}$ & $\begin{array}{c}-1.74 * * \\
(-2.43)\end{array}$ & $\begin{array}{c}-1.47 * * \\
(-1.98)\end{array}$ & $\begin{array}{l}-0.27 \\
(-0.26)\end{array}$ \\
\hline MOMH- MOML & $\begin{array}{c}-0.54 \\
(-1.29)\end{array}$ & $\begin{array}{c}-0.49 \\
(-1.52)\end{array}$ & $\begin{array}{c}-0.05 \\
(-0.09)\end{array}$ & $\begin{array}{c}0.23 \\
(0.60)\end{array}$ & $\begin{array}{c}-0.50 \\
(-1.21)\end{array}$ & $\begin{array}{l}-0.05 \\
(-0.49)\end{array}$ \\
\hline \multicolumn{7}{|l|}{ Past DN market } \\
\hline MOM-L & $\begin{array}{c}-8.27 * * \\
(-2.36)\end{array}$ & $\begin{array}{c}-9.37 * * * \\
(-2.74)\end{array}$ & $\begin{array}{c}1.10 \\
(0.22)\end{array}$ & $\begin{array}{c}9.25 * * * \\
(4.24)\end{array}$ & $\begin{array}{c}10.30 * * * \\
(4.88)\end{array}$ & $\begin{array}{l}-1.05 \\
(-0.34)\end{array}$ \\
\hline MOM-H & $\begin{array}{l}-6.65^{* *} \\
(-2.26)\end{array}$ & $\begin{array}{l}-7.85^{* *} \\
(-2.42)\end{array}$ & $\begin{array}{c}1.21 \\
(0.28)\end{array}$ & $\begin{array}{c}6.86 * * * \\
(3.56)\end{array}$ & $\begin{array}{l}8.91 * * * \\
(4.50)\end{array}$ & $\begin{array}{l}-2.05 \\
(-0.74)\end{array}$ \\
\hline MOMH- MOML & $\begin{array}{c}1.62 \\
(1.45) \\
\end{array}$ & $\begin{array}{c}1.51 \\
(1.42) \\
\end{array}$ & $\begin{array}{c}0.11 \\
(0.07) \\
\end{array}$ & $\begin{array}{c}-2.39 * * * \\
(-4.17) \\
\end{array}$ & $\begin{array}{c}-1.39 * * \\
(-2.02)\end{array}$ & $\begin{array}{c}-1.00 \\
(-1.13) \\
\end{array}$ \\
\hline \multicolumn{7}{|c|}{ Panel E: TS momentum returns sorted on market dynamics and $V O L$} \\
\hline & \multirow{2}{*}{\multicolumn{3}{|c|}{ Islamic (A) $\frac{\text { Subsequent UP }}{\text { Non-Islamic (B) }}$}} & \multicolumn{3}{|c|}{ Subsequent DN } \\
\hline & & & & Islamic (A) & Non-Islamic (B) & A-B \\
\hline \multicolumn{7}{|l|}{ Past UP market } \\
\hline MOM-L & $\begin{array}{c}2.96 * * * \\
(4.30)\end{array}$ & $\begin{array}{l}3.19 * * * \\
(4.02)\end{array}$ & $\begin{array}{l}-0.23 \\
(-0.45)\end{array}$ & $\begin{array}{l}-1.02 \\
(-1.62)\end{array}$ & $\begin{array}{c}-0.97 \\
(-1.61)\end{array}$ & $\begin{array}{l}-0.05 \\
(-0.06)\end{array}$ \\
\hline MOM-H & $\begin{array}{c}4.29 * * * \\
(4.23)\end{array}$ & $\begin{array}{c}4.10 * * * \\
(3.88)\end{array}$ & $\begin{array}{c}0.19 \\
(0.13)\end{array}$ & $\begin{array}{c}-2.76 * * * \\
(-2.73)\end{array}$ & $\begin{array}{c}-2.37 * * \\
(-2.38)\end{array}$ & $\begin{array}{c}-0.39 \\
(-0.27)\end{array}$ \\
\hline MOMH- MOML & $\begin{array}{l}1.33 * * \\
(2.15)\end{array}$ & $\begin{array}{l}0.91 * \\
(1.73)\end{array}$ & $\begin{array}{c}0.42 \\
(0.77)\end{array}$ & $\begin{array}{c}-1.74 * * * \\
(-3.20)\end{array}$ & $\begin{array}{c}-1.41 * * \\
(-2.58)\end{array}$ & $\begin{array}{l}-0.33 \\
(-0.43)\end{array}$ \\
\hline \multicolumn{7}{|l|}{ Past DN market } \\
\hline MOM-L & $\begin{array}{c}-6.63 * * \\
(-2.24)\end{array}$ & $\begin{array}{c}-7.21 * * \\
(-2.60)\end{array}$ & $\begin{array}{c}0.58 \\
(0.14)\end{array}$ & $\begin{array}{c}8.96 * * * \\
(4.25)\end{array}$ & $\begin{array}{c}8.72 * * * \\
(4.87)\end{array}$ & $\begin{array}{c}0.24 \\
(0.09)\end{array}$ \\
\hline MOM-H & $\begin{array}{c}-9.71 * * \\
(-2.29)\end{array}$ & $\begin{array}{c}-10.89 * * \\
(-2.54)\end{array}$ & $\begin{array}{l}1.18 \\
(0.19)\end{array}$ & $\begin{array}{c}9.51 * * * \\
(3.55)\end{array}$ & $\begin{array}{l}11.70 * * * \\
(4.42)\end{array}$ & $\begin{array}{l}-2.19 \\
(-0.58)\end{array}$ \\
\hline MOMH- MOML & $\begin{array}{c}-3.08 * * \\
(-1.96) \\
\end{array}$ & $\begin{array}{l}-3.68^{*} \\
(-1.91) \\
\end{array}$ & $\begin{array}{c}0.60 \\
(0.24) \\
\end{array}$ & $\begin{array}{c}0.55 \\
(0.38) \\
\end{array}$ & $\begin{array}{l}2.98 * * \\
(2.28)\end{array}$ & $\begin{array}{l}-2.43 \\
(-1.24) \\
\end{array}$ \\
\hline
\end{tabular}

